\title{
ARTICLE
}

\section{Fiscal consolidation and the sustainability of public debt in the GIPSI countries}

\author{
Manel Antelo ${ }^{\mathrm{a}, *}$, David Peón ${ }^{\mathrm{b}}$ \\ a University of Santiago de Compostela, Department of Foundations of Economic Analysis, 15782 Santiago de Compostela, Spain \\ ${ }^{\mathrm{b}}$ BBVA Group and University of A Coruña, Department of Finance and Accounting, 15701 A Coruña, Spain
}

Received 4 June 2013; accepted 1 October 2013

Available online 16 November 2013

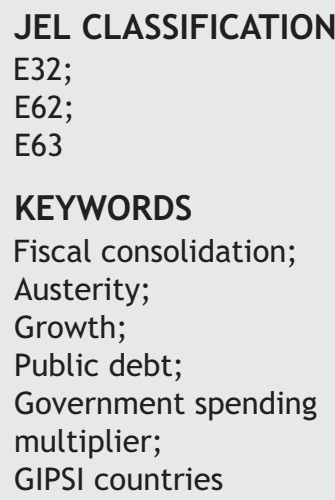

\section{KEYWORDS}

Fiscal consolidation; Austerity;

Growth;

Public debt;

Government spending multiplier;

GIPSI countries

\section{CÓDIGOS JEL}

E32;

E62;

E63

\section{PALABRAS CLAVE}

Consolidación fiscal; Austeridad;

Crecimiento; Deuda pública; Multiplicador del gasto público; Países periféricos

\begin{abstract}
Correcting fiscal imbalances and reducing public debt is a priority among the peripheral countries of the Eurozone (the so-called GIPSI countries). However, there is no consensus about which is the most appropriate policy mix to achieve it: the debate on fiscal austerity vs. growth is bitter now among researchers and international policymakers. In this paper we review the effects of different fiscal consolidation policies on macroeconomic performance. We also provide an empirical analysis that complements the recent study performed by the IMF regarding the sustainability of public debt for GIPSI countries in different scenarios of growth, inflation, and fiscal and monetary policies. Finally, a policy mix is offered that would be suitable for these five countries to achieve both fiscal consolidation and economic growth.
\end{abstract}

๑ 2013 Asociación Cuadernos de Economía. Published by Elsevier España, S.L. All rights reserved.

\section{Consolidación fiscal y sostenibilidad de la deuda pública en los países GIPSI}

Resumen Corregir los desajustes fiscales y reducir la deuda pública son dos objetivos prioritarios para los países periféricos de la Eurozona, si bien no existe consenso sobre la política más adecuada para alcanzarlos. En este artículo repasamos los efectos que las diferentes políticas de consolidación fiscal tienen sobre los agregados macroeconómicos y ofrecemos un análisis empírico que complementa el reciente estudio del FMI sobre la sostenibilidad de la deuda pública en los citados países en diferentes escenarios de crecimiento, inflación, y políticas fiscales y monetarias. Asimismo, describimos la política que consideramos más deseable para los

\footnotetext{
* Corresponding author.

E-mail address: manel.antelo@usc.es (M. Antelo).
}

0210-0266/\$ - see front matter @ 2013 Asociación Cuadernos de Economía. Published by Elsevier España, S.L. All rights reserved. 
países de la periferia de la Eurozona al objeto de alcanzar la consolidación fiscal y el crecimiento económico.

(C) 2013 Asociación Cuadernos de Economía. Publicado por Elsevier España, S.L. Todos los derechos reservados.

\section{Introduction}

Correcting fiscal imbalances and reducing public debt is a priority now for most countries, particularly for the peripheral countries of the Eurozone (namely Greece, Ireland, Portugal, Spain and Italy, a.k.a. GIPSI countries). Indeed, public debt in advanced economies has climbed to its highest level since World War II, now exceeding 100\% of GDP (IMF, 2012d), while this threshold has been largely surpassed by countries like Portugal, Ireland, Italy and Greece. ${ }^{1}$

There is no consensus about which policy strategy should be implemented in order to achieve a fiscal consolidation while not jeopardizing economic growth. The debate about fiscal austerity vs. economic growth is bitter now among researchers and practitioners. Obviously, both fiscal consolidation and economic growth are desirable outcomes, but while some authors argue in favour of expansionary (non-Keynesian) effects of austerity, others claim it is self-defeating. After the expansionary fiscal and monetary policies of 2009, most countries bet for austerity at that time. For instance, Corsetti et al. (2010) mention how, with the ongoing economic recovery, the goal of economic policies was shifting to fiscal exit strategies, including both tax increases and sizeable spending cuts. However, most advanced economies are now showing a growth slowdown, when not of a deep recession. The recent World Economic Outlook by the IMF (IMF, 2012d) has only intensified the debate, when it attributed relevant contractionary effects to fiscal austerity.

The contribution of this paper is threefold. First, we provide a deep insight into the literature on public debt deleverage and the effects of fiscal consolidation, in search for a synthesis whenever it is possible. Second, we conduct an empirical analysis of macroeconomic scenarios for the GIPSI countries to highlight the relationship between the sustainability of public debt and different levels of growth, inflation, fiscal and monetary policies, and we compare our results with those of the recent study by the IMF (IMF, 2012d). Finally, we provide a policy mix that would be the most suitable for these five countries, in order to achieve a combination of fiscal consolidation and economic growth, according to the theoretical literature and the empirical findings in both our paper and the IMF's research.

\footnotetext{
${ }^{1}$ According to Eurostat, at the end of 2011 Portugal and Ireland had a ratio of $108 \%$ of public debt over GDP, Italy $120 \%$ and Greece $165 \%$. Spain was the only country to be analyzed in this article that did not surpassed the $100 \%$ threshold yet $(69 \%)$, though it was expected to reach $90 \%$ by the end of 2012, according to IMF (IMF, 2012b) and the Spanish Government.
}

The rest of the article is organized as follows. Section 2 reviews the theoretical literature on public debt deleverage and fiscal consolidation. We search for synthesis elements when available, while stressing the main points of controversy otherwise. In Section 3 we conduct an empirical study in order to analyze the sustainability of the public debt of GIPSI countries in different macroeconomic scenarios. Section 4 compares the results of our analysis with those of the IMF (IMF, 2012d). Finally, we provide in Section 5 a policy mix to achieve both fiscal consolidation and economic growth.

\section{The state of the art on public debt deleverage}

Deleveraging an economy refers to the process of reducing public and private debt levels expressed as a ratio of total debt-to-GDP. Defined as the subscription of debts or loans that multiply the financial capacity of an agent, leverage has always represented a common means of financing by the States. This way, the resources raised through taxes are complemented, particularly during recessions, with the issuing of new debt.

The virtues of financial leverage are a classic issue in the literature of corporate finance, from the irrelevance of capital structure under ideal conditions (Modigliani and Miller, 1958) to the multiplier effect of indebtedness (see, for example, the literature on financial risk and leverage measures in Briley et al., 2010), and similar interpretations could apply to public debt. However, it is also true that leverage conveys a substantial increase in risk exposure, which might become harmful if a financial crisis occurs. Indeed, the recent financial crisis abruptly ended the leveraging process of the private sector, while the increasing exposure to debt by the public sector was a consequence of both automatic stabilizers and the expansionary policies that most countries implemented at that time.

Then, since 2010 most economic authorities shifted their strategies in order to implement a fiscal consolidation that would correct fiscal imbalances. Since 1980, 84 advanced and developing economies were able to reduce their debtto-GDP ratios in more than 20 percentage points in at least two years (Finger and Sadikov, 2010). Mean debt reduction was $34 \%$ of GDP, lasting 5 and a half years, with a primary surplus ratio of $2.75 \%$ of GDP on average. However, in many other cases the success has only been moderate: for the 26 identified episodes by the IMF (IMF, 2012d) during the 20th century, the median debt-to-GDP ratio after 15 years was only about 10 percentage points lower. Things seem to be even tougher nowadays: recent fiscal consolidation processes led most economies into a recession while they have been unable to correct fiscal imbalances significantly. 
Are we cursed? Is it a combination of fiscal consolidation and economic growth impossible today? To answer this question, let's first analyze the options available. Following McKinsey (2011, 2012), four are the possible deleverage strategies. First, tighten our belts (the most common way to deleverage, in order to increase net savings, is to reduce public expenditures during a long period of fiscal austerity); second, generate inflation because a higher inflation increases nominal GDP growth, making debt-to-GDP ratios lower ${ }^{2}$; third, debt restructuring and/or default ${ }^{3}$; and fourth, growing at a higher rate than the debt accumulation (if an economy is able to do so, the debt-to-GDP ratio decreases automatically). ${ }^{4}$ Countries that undertook successful fiscal consolidations in the past could be split into three groups: oil-exporting countries, who benefited from a favourable situation; countries that restructured their debt, they received support from their creditors and exhibited a quick recovery; and countries that were able to combine fiscal consolidation policies with a favourable dynamics of debt. Some of these strategies are not desirable (default should be the last option), while other experiences are not imitable today by advanced countries (like the success experienced during catch up processes, by small exporting countries, etc.).

Henceforth, a successful deleverage process critically depends on being able to combine fiscal consolidation, inflation and growth. However, there is no consensus about how to do it. Indeed, few debates in Economics are so controversial as the effects of fiscal policies on the main macroeconomic variables (particularly on consumption and, hence, on economic growth), whether we should or not use deficits and debt to finance fiscal expenditures, and whether austerity might have expansionary (non-Keynesian) effects over GDP through a cost of debt reduction. Opinions are, quite often, conflicting, so making up a synthesis is a difficult task. On one hand, a school of thought refuses to make use of debt to overcome a recession, an opinion summarized by stating that a problem created by debt cannot be solved by running up more debt. On the other hand, the opposite view is expressed as follows by Eggertsson and Krugman (2012, pp. 1469-1471)

"You cannot solve a problem created by debt by running up more debt' - say the critics (...). What is wrong with that argument? It assumes, implicitly, that debt is debt it does not matter who owes the money. Yet that cannot be right; (...) debt is money we owe to ourselves (...): the level of debt matters only if the distribution of that debt matters.

At the same time, the heated debate about the effects of demand-side policies through the increase of public spending versus fiscal consolidation is illustrated by Cogan et al. (2010, p. 282) as follows:

Macroeconomists remain quite uncertain about the quantitative effects of fiscal policy. This uncertainty derives

\footnotetext{
2 The most relevant example might be Chile, from 1984 to 1991.

${ }^{3}$ Historically, this strategy appears to be common after a severe monetary crisis.

${ }^{4}$ Like the U.S. did from 1938 to 1943.
}

not only from the usual errors in empirical estimation but also from different views on the proper theoretical framework and econometric methodology.

Theoretical literature on deleverage of the public sector deals with three broad topics. First, the role of public debt as a common means of financing by States, summarized in three questions. What is the relationship between levels of debt and long term economic growth? Which negative effects are produced by high stocks of debt and through which mechanisms are those effects transmitted? Is there a threshold for the debt-to-GDP ratio above which it would be advisable to start a deleverage process?

A second debate addresses fiscal consolidation. Several questions are in order. Is there a threshold for the public deficit an economy should not exceed? Is it appropriate to impose a zero-deficit rule? Are measures of structural deficits reliable? Could fiscal consolidation generate growth under recessions or, equivalently, is austerity expansionary? Is it preferable a smooth and gradual consolidation to an aggressive one? Should fiscal consolidation be implemented by increasing revenues or by cutting expenses? All these questions are related to the classic debate about the estimation of the government spending multiplier.

A third topic refers to the current context where the processes of fiscal consolidation and deleverage are being implemented. Given private sector is also highly indebted and the prospect for most advanced economies is a low economic growth for some time, if both the private and public sectors deleverage at the same time... who is to be leading the recovery? Sure the other side of the problem is that the current context is also characterized by the high cost of debt peripheral countries in the Eurozone are required to pay. Given this, which possibilities do their governments have to keep financing growth with new debt? Sections 3 and 4 are devoted to this dilemma. For now, let us examine the two first topics: the role of public debt and fiscal consolidation.

\subsection{Public debt}

"The United States debt, foreign and domestic, was the price of liberty"'

Alexander Hamilton ${ }^{5}$

Public debt has always been commonly used by national and regional governments for financing purposes. National budget is largely financed through different taxes, yet these are usually not enough to cover expenditures assumed by the authorities, particularly in the recessive phase of the cycle. Thus, the generated deficit must be financed by means of public-debt issuing. Fig. 1 shows the public debt-GDP ratio of some economies throughout the last 17 years.

However, public-debt accumulation is not innocuous. There is extensive academic consensus on the harmful effects of high public-debt levels, as well as on the

\footnotetext{
${ }^{5}$ Alexander Hamilton was the first United States Secretary of the Treasury, from 1789 to 1795. Quoted on Public Debt, the U.S. Department of the Treasury website (available at http: //www.publicdebt.treas.gov/).
} 


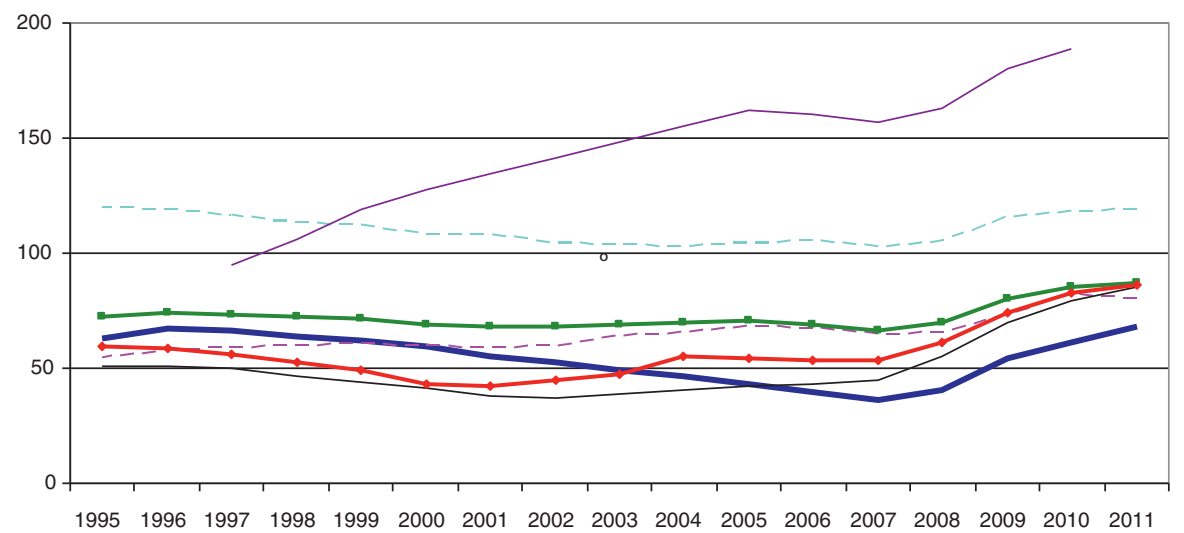

$\begin{array}{lllllllllllllllll}1995 & 1996 & 1997 & 1998 & 1999 & 2000 & 2001 & 2002 & 2003 & 2004 & 2005 & 2006 & 2007 & 2008 & 2009 & 2010 & 2011\end{array}$

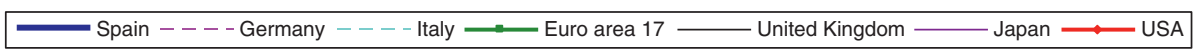

Figure 1 Public debt-to-GDP ratio (\%).

Source: ECB Statistical Data Warehouse.

available mechanisms through which these levels have a negative impact on the main macroeconomic aggregates.

Public debt has several negative effects on economic activity. Firstly, the higher public debt is, the higher its cost. This is a ceteris paribus effect, since interests grow even when average financing rate in the market holds constant. Consequently, this effect is more intense when higher public-debt ratios lead investors to demand a higher return for the purchased securities, so debt load increases twice over. Thus, either some of the State-collected taxes are devoted to unproductive purposes (repaying debt's interests), or deficit must be resorted to. Secondly, this leads to a further negative effect: incurring in higher levels of debt may demand greater financing through deficit, which is incorporated to the debt stock, thus generating a spiral that may turn out to be explosive under certain circumstances that shall be analyzed later. Thirdly, in case of no deficit financing, this could be made through tax collection. However, this strategy increases economic distortions and hence inefficiency (Barro, 1979). Another alternative would be a faster money creation by authorities, though this might lead to higher inflation and inflation-related distortions (Sargent and Wallace, 1981). Finally, another way public debt might harm macroeconomic variables is the crowding-out effect: as public debt produces the perception of greater wealth in the economy's private sector, it may reduce the accumulation of real assets (Auerbach, 2009).

All these effects would explain, according to literature, the existing direct relationship between high debt levels and lower economic growth. Indeed, Reinhart and Rogoff $(2009,2010 a, b)$ recently proved this debt-growth correlation for 44 countries throughout 200 years. The $90 \%$ threshold for the debt-GDP ratio was their most relevant conclusion:

The relationship between government debt and real GDP growth is weak for debt/GDP ratios below $90 \%$ of GDP. Above the threshold of $90 \%$, median growth rates fall by $1 \%$, and average growth falls considerably more. The threshold for public debt is similar in advanced and emerging economies and applies for both the post World War II period and as far back as the data permit (often well into the 1800s) (Reinhart and Rogoff, 2010a).
Posterior empirical studies (Kumar and Woo, 2010; Cecchetti et al., 2011) proved this negative correlation between public debt and growth is especially intense when debt volume approaches $100 \%$ of GDP. ${ }^{6}$ Nevertheless, there is some debate on the causal effect of this correlation. Reinhart and Rogoff state that causality is bidirectional, while Panizza and Presbitero (2012a,b) provide empirical evidence that it is slow economic growth episodes which lead to debt accumulation and not the other way around.

Accumulating debt therefore does not seem a good business. This is not surprising either. Everyone would prefer owning his own house without mortgages and having debtfree assets. Then, why to make use of debt? Because though everyone would prefer to avoid the mortgage when buying a house, for many young people this would be equivalent to having to save money for 30 years. When they are, say 55, they could thank mum and dad for their generous hospitality, and leave their house to buy their own one... perhaps a bit too late now! Likewise, the fact that States finance long-term investments (e.g., motorways) through debt is justifiable, as these investments are meant to benefit both present and future generations. Making use of deficit and debt in the downward stages of the cycle as long as it is compensated by surplus in upward stages does not seem illogical either. $^{7}$

In short, the most extended vision is that making use of debt is acceptable as long as it is sustainable and does not harm long-term growth. ${ }^{8}$ The second requirement depends,

\footnotetext{
${ }^{6}$ We deal with 90 and 100\% thresholds because they are reference values. As Reinhart and Rogoff (2010a) point out, the $90 \%$ threshold does not mean that growth will be normal at $89 \%$ and subpar at $91 \%$, as a $90 \mathrm{~km} / \mathrm{h}$ speed limit does not mean that driving $89 \mathrm{~km} / \mathrm{h}$ is safe and $91 \mathrm{~km} / \mathrm{h}$ leads to an accident with complete certainty.

7 See the concept of structural deficit below.

8 Auerbach (2009) points out a third reason why high debt levels would not be desirable: the intergenerational nature of debt load. According to this interpretation, public debt would be a bond transferred from present-day to future generations. Against this approach, other authors argue that both deficit and debt can be assumed as long as they finance long-term investments, but not
} 
Table 1 Public debt barometer for several countries in 2012. ${ }^{a}$

\begin{tabular}{lccrr}
\hline & PSR 2011 & $(1)$ PSR $2012_{(f)}$ & $(2) \frac{\text { Debt }}{\text { GDP }} \times(i-g)$ & $(1)-(2)$ \\
\hline Germany & 1.6 & 1.0 & -0.2 & 1.2 \\
Italy & 1.0 & 3.0 & 4.5 & -1.5 \\
France & -2.6 & -2.2 & 0.5 & -2.7 \\
U.S. & -7.3 & -6.1 & -1.9 & -4.2 \\
U.K. & -5.0 & -5.3 & -1.0 & -4.3 \\
Spain & -6.1 & -3.6 & 3.9 & -7.5 \\
Japan & -9.1 & -8.9 & -1.3 & -7.6 \\
Ireland & -6.7 & -4.4 & 5.1 & -9.5 \\
Portugal & -0.4 & 0.1 & 9.9 & -9.8 \\
Greece & -2.2 & -1.0 & 41.4 & -42.4 \\
\hline
\end{tabular}

Source: Own elaboration from ECB, IMF (2012a,b,c), Eurostat and Bloomberg.

a To calculate the primary fiscal surplus (or primary surplus ratio, PSR) for 2012 we used the IMF estimates (2012a). On the other hand, to obtain the PSR for 2011 we used ECB Statistical Data Warehouse except for Ireland, U.S. and Japan, also IMF (2012a). Finally, to calculate the required PSR according to the barometer of debt, we used 2011 data from Eurostat for the debt-to-GDP ratio, except Japan (the latest available data is from 2010). Cost of debt is measured by nominal rates on 10-year Treasuries (details at the end of August 2012), according to Eurostat for European countries or Bloomberg for others. For the nominal growth rate of GDP we use estimates for 2012 from Eurostat for the euro area countries, while for the U.K., Japan and U.S. correct the estimated real growth for 2012 as the IMF World Economic Outlook (IMF, 2012c) with the deflator estimated by Eurostat to these countries (and which is the latest data available in the second quarter of 2012). Since these estimates use various sources, comparison among countries is not entirely homogeneous, though reasonably good.

as already mentioned, on the around-100\% threshold of the debt-to-GDP ratio. Sustainability depends, apart from the accumulated stock of debt, on the cost of debt and the economic growth. The golden rule of long-term debt sustainability states that:

if the average rate of annual nominal/real growth of a country is below the average nominal/real interest rate of the annual cost incurred in debt refinancing, debt will become unsustainable and investors shall give up financing it (de la Dehesa, 2012a,b).

In this respect, the Kiel Institute Barometer for Public Debt (Bencek and Klodt, 2011) considers that, for the public debt-GDP ratio to hold stable, the primary surplus ratio, ${ }^{9}$ PSR, must be equal to or higher than the debt-GDP ratio multiplied by the difference between the debt's nominal interest rate, $i$, and GDP's annual nominal growth rate, $g$. Formally,

$\mathrm{PSR} \geq \frac{D}{\mathrm{GDP}} \times(i-g)$.

Hence, in order to remain solvent any Government that cannot get financed in the market at a nominal rate below

current expenses. This is why some authors (e.g., de la Dehesa, 2012a,b) suggest that public investment by EU countries (supervised by European Union (EU) authorities) should not be taken into account in deficit calculations, thus helping to generate growth, as it occurs in US States.

${ }^{9}$ The primary surplus ratio is the primary fiscal surplus relative to GDP. Primary fiscal deficit or surplus is the result obtained from comparing total incomes and expenses in the public sector, excluding debt interest. This concept measures the part of fiscal deficit or surplus that can be directly controlled, since debt services is to a large extent conditioned by economy in general. The concept was created by the IMF in the 1990s to measure the amount that the different States promised to devote to pay their debt interests. its economic growth must be able to run a primary surplus ratio. Furthermore, this surplus must also be the larger the higher the stock of debt accumulated. The same conclusion is drawn by a recent IMF empirical study (Devries et al., 2011), which states that, according to the analysis of 173 fiscal adjustments in 17 OECD countries between 1978 and 2009, the likelihood of a fiscal adjustment in a given country increases as (i) its fiscal imbalance grows, (ii) its growth rate falls, and (iii) its long-term debt interest rate increases. Table 1 shows the situation as of 2012 for the main countries in the Eurozone, the U.K., the U.S. and Japan regarding fiscal surplus in their public accounts relative to that required by the golden rule. All countries except Germany fail to fulfil the required fiscal balance.

In short, these are the three recommendations contributed by academic consensus. Firstly, control primary deficit. Secondly, prioritize the use of deficit and debt to finance investment instead of current expenditures. Thirdly, from a given debt-to-GDP threshold deleveraging seems advisable: on one hand, higher ratios damage growth; on the other hand, starting a deleverage process becomes more urgent as debt cost increases relative to economic growth.

The academic consensus only reaches this far. Regarding the use of debt, new Keynesian and neoclassic economists differ substantially, since the former have always been more

Table 2 Gross households debt (in \% over personal income).

\begin{tabular}{lrl}
\hline & 2000 & 2008 \\
\hline United States & 96 & 128 \\
United Kingdom & 105 & 160 \\
Spain & 69 & 130 \\
\hline
\end{tabular}

Source: McKinsey Global Institute (2010) via Eggertsson and Krugman (2012). 
prone to using debt as a fiscal policy due to the positive effects of growth under some specific conditions. Keynesians suggest there is an additional reason to use debt that would be particularly relevant in situations such as the present one: when the (even more indebted) private sector needs to be relieved by the public sector. Table 2 shows the strong increase of debt in national economies in the years before the crisis outbreak in three different countries.

The concept of balance sheet recession, developed by Koo (2008), argues that the present-day crisis, as well as Japan's crisis two decades ago, would be characterized by high levels of private debt. In this context, de-capitalization of companies and banks in face of the significant drop in prices of assets (e.g., toxic assets) in their balance sheets renders monetary policies ineffective: companies assume no more debts when rates are at $0 \%$, because their main problem is precisely debt! Companies change their objective of maximizing profits to minimizing debts and, even with $0 \%$ rates, employ the generated resources to reduce debt. The orthodox theory cannot explain this behaviour: if their managers are "so stupid" [sic] not to benefit from money at $0 \%$ rate, why should they keep on running these companies? The best they could do is giving money back to shareholders and close! - says Koo.

Bearing in mind this and other concepts, Eggertsson and Krugman (2012) argue that the need to deleverage by the private sector is a favourable reason to increase public debt in the current situation. ${ }^{10}$ When a significant part of the economy is debt-constrained it leads to a depressed aggregate demand, since large sectors of the economy are unable to spend due to their excessive debt. If deleveraging in the private sector is large enough, the economy ends up against the zero lower bound (ZLB); the economy is then likely to fall into a liquidity trap; price drop leads to increased debt load, extending the initial shock effect; the paradoxes of frugality and effort (Eggertsson, 2010) would emerge in a context of rigid prices while increasing price flexibility would only worsen the debt crisis; finally, more (public) debt, by means of expansive fiscal policies, may be the solution to a debtinduced slump. This is due to the fact that, precisely when the private sector is debt-constrained, the Ricardian equivalence breaks down, ${ }^{11}$ current consumption would depend on the current income, the multiplier of public spending would be over 1 and, thus, all this would logically support expansive fiscal policies.

Some authors have recently offered similar arguments. Hall (2011) argues that households' restrictions due to high debt levels are essential to explain the crisis in the U.S. Mian and Sufi $(2011 a, b)$ also show that differences in debt overhang across U.S. counties explain the higher unemployment

\footnotetext{
10 Eggertsson and Krugman (2012) cite three antecedents to their model: the argument of Fisher (1933) that Great Depression was due to a vicious circle in which the fall of the prices of assets increased the real debt load; the theory on the cyclical instability of credit by Minsky (1986), where long periods of prosperity lead to indulgence regarding debts and the virtues of leverage; and the concept of balance sheet recession by Koo (2008), according to which large sectors of the economy are unable to spend due to their excessive debt.

11 See Section 2.2.
}
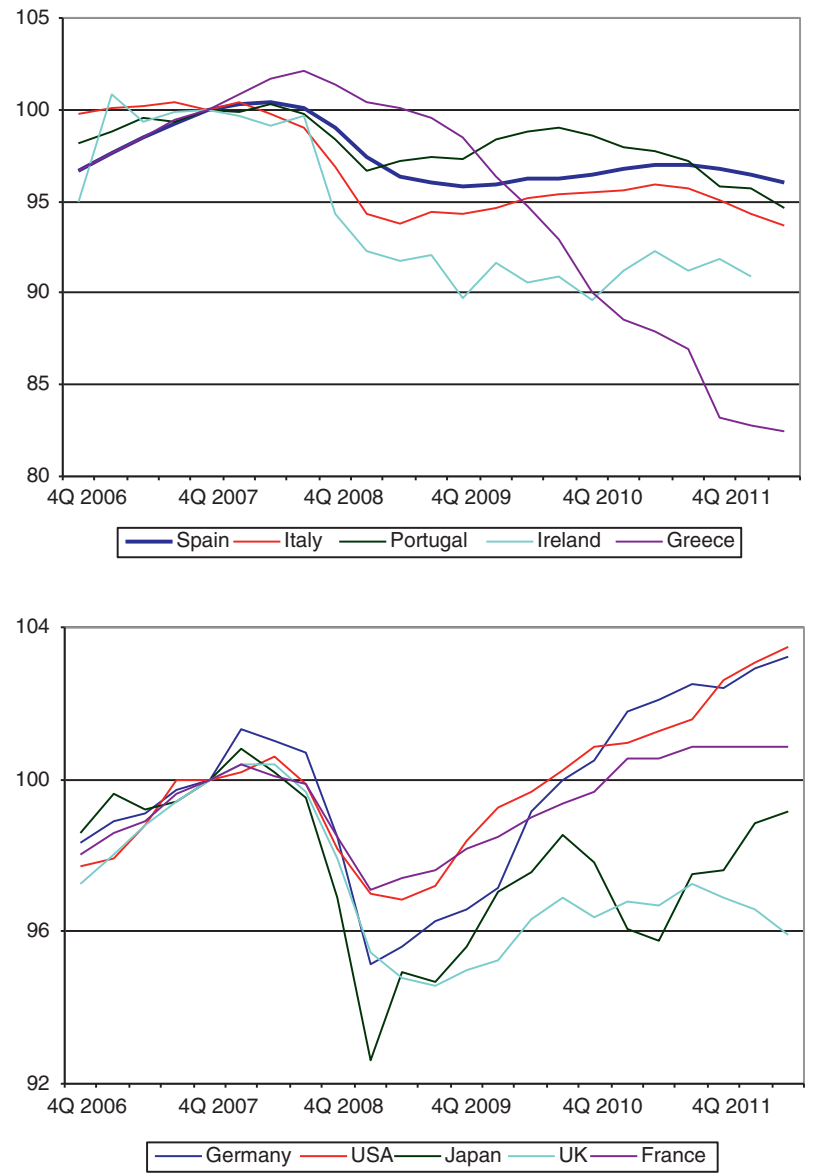

Figure 2 Accumulated quarterly GDP (base $100=4 Q 2007$ ). Source: Own elaboration from Eurostat.

rates in some regions. Anyway, this Keynesian approach suggesting higher (public) debt may resolve a (private) debt problem leads to the classical debate on the government spending multiplier and the goodness of fiscal policies versus the neoclassical concept of expansive austerity.

\subsection{Fiscal consolidation}

After the Keynesian stimuli that were implemented since late 2008 to solve world financial crisis, economic policy recommendations have changed since 2010 towards an approach more focused on fiscal consolidation. This should help ensure the sustainability of public finances, highly damaged by the expansive policies and by the fall of tax collection in a context of strong recession. Some academics also supported the idea that a fiscal consolidation strategy would be welcomed by debt markets, thus increasing agents' confidence in the government's capacity to solve the crisis and, consequently, producing non-Keynesian effects on the economic activity. This would be the so-called expansive austerity.

However, the economic performance by most economies, particularly in southern Europe, since mid-2011 and the prospects of European and international authorities point out to a double dip, or to an economic stagnation at best, as shown in Fig. 2. 
The performance is particularly negative in the Eurozone, the world region with the lowest economic growth in the last two consecutive decades; simultaneous fiscal contraction in all its member countries is currently aggravating this situation. Authorities and academics are now concerned: Can fiscal consolidation indeed generate growth in this recessive context? That is, is austerity expansive? Are slow and gradual consolidations preferable to more aggressive strategies? Is it preferable to consolidate by increasing revenues or reducing spending? All these questions lead to the debate on the value of the government spending multiplier. ${ }^{12}$

There is no consensus either in theoretical or empirical literature on the effects of expansionary fiscal policy. Theoretical literature is divided into two approaches: neoclassical of real business cycle (RBC) models (Aiyagari et al., 1992; Baxter and King, 1993), and new Keynesian (Rotemberg and Woodford, 1992; Devereux et al., 1996). A basic difference that explains the diverging results between both approaches is the concept of Ricardian equivalence ${ }^{13}$ of public debt: it is indifferent whether a government finances a particular public spending level through debt or taxes, as it has no first-order effects on aggregate demand, interest rates, private investment, etc. (Barro, 1979). Why? Because consumers act as if they lived an infinite life (as a dynasty) and consequently issuing public debt would have no net marginal effect on their wealth as long as there is an operational chain for intergenerational wealth transfer that connect present-day and future generations (Barro, 1974). In other words, given that debt must be eventually paid (presumably with higher taxes in the future), consumers perceive the choice between raising taxes or issuing new debt as equivalent to paying taxes today or in the future.

In this situation, the neoclassical RBC approach states that the optimal response of consumers to a permanent increase in public spending is reducing consumption and increasing their labour offer (Ramey, 2011). The government spending multiplier would then be below 1 due to this crowding-out effect motivated by the negative wealth effect of higher taxes today or in the next future (Baxter and King, 1993). The timing of tax collection is irrelevant if collected in a lump sum basis, i.e. if the Ricardian equivalence holds (Cogan et al., 2010).

On the contrary, the standard new Keynesian model (Rotemberg and Woodford, 1999) predicts that a permanent increase in public spending leads to increased private consumption, actual wages, and productivity, amplifying the effects of tax policies (Galí et al., 2007). According to the IS-LM model, non-Ricardian consumers whose consumption depends on their current disposable income are assumed. In spite of this, unlike the old Keynesian school, the standard new Keynesian model does assume agents' rational expectations, yet combined with some sort of price rigidity (Cogan et al., 2010) motivated by oligopolistic competition

\footnotetext{
12 That is, the increase of the annual GDP growth rate with an expansive fiscal policy or, alternatively, the reduction of the annual GDP growth rate per each percentage point of fiscal deficit reduction relative to DGP (increasing fiscal incomes and/or reducing public spending).

13 David Ricardo was, back in the 19th century, the first author who proposed this theory, and Robert Barro retook it in the 1970s.
}

and increasing returns to scale (Ramey, 2011). Several modifications to this base model have been proposed, bringing it closer to the neoclassical or more traditional Keynesian interpretations. ${ }^{14}$

The debate between both theoretical models would be solved with clear empirical evidence in favour of any of them, yet this is not the case. ${ }^{15}$ However, some progress has been made and there is a growing consensus now, ${ }^{16}$ from methodological aspects (e.g., Woodford (2009) ${ }^{17}$ contributes a complete review on this issue) to policy recommendations. Focusing on the latter, the main consensus elements are referred to: (i) the value of the multiplier both in general and under special circumstances; (ii) fiscal consolidation through reduced public spending or increased tax collection; (iii) the short- and long-term effects of fiscal consolidation; and (iv) the suitable timing of fiscal consolidation.

\subsubsection{The government spending multiplier}

New Keynesian general equilibrium models estimate the value of the public spending multiplier in normal circumstances could be above or below 1 depending on the way agents' preferences are specified (Galí et al., 2007; Monacelli and Perotti, 2008). Alternatively, RBC models generally obtain a below-1 multiplier (Aiyagari et al., 1992; Baxter and King, 1993; Ramey and Shapiro, 1998; Burnside et al., 2004). Most empirical results estimate a multiplier value that ranges between 0.8 (Barro, 1981) and 1.2 (Ramey, 2011). Therefore, it is hard to argue that the public spending

\footnotetext{
14 The new Keynesian model of rational expectations and price rigidity has been criticized for both being too Keynesian or not Keynesian enough (Cogan et al., 2010). On one hand, it would be not Keynesian enough as it assumes rational expectations and optimization of spending decisions. Thus, other models assume that either some share of consumers follows rules-of-thumb, or that households are constrained to consume all their current income (e.g., Galí et al., 2007). On the other hand, those who consider it too much Keynesian consider it assumes sticky prices in a mechanical way that amplifies Keynesian effects on aggregate demand (Chari et al., 2009).

15 See Section 3.

16 Some authors do not see it this way. Mankiw (2006), for instance, states that since the 1970 s macroeconomists have focused too much on conceptual fundamentals, yet scarcely on macroeconomics as a tool to solve practical problems through the implementation of monetary and fiscal policies. In Mankiw's words, the problem is that God put macroeconomists on Earth not to propose and test elegant theories but to solve practical problems (p. 29).

17 Woodford (2009) points out five elements in the New Neoclassical Synthesis (macroeconomic examples of formerly contentious issues about which there is wide consensus nowadays). Firstly, macroeconomic analysis is widely accepted to use coherent intertemporal general equilibrium foundations. Secondly, quantitative analysis of economic policies should be based on econometrically validated structural models. Thirdly, it is important to model expectations as endogenous, so that policy analysis takes into account the way in which expectations may differ if alternative policy were to be implemented. Fourthly, real perturbations are an important source of economic fluctuations, including not only RBC technological shocks but also those referred to the agents' preferences or public policies. Finally, monetary policy is considered effective, especially as a mechanism for inflation control.
} 
multiplier is, generally speaking, substantially larger than 1 (Christiano et al., 2011).

However, things change under abnormal circumstances. On one hand, multipliers are usually higher during a recession (de la Dehesa, 2012a). Thus, this would be an argument against fiscal consolidations, at least aggressive ones, in bad times. Besides, most of the new Keynesian literature is focused on the effectiveness of fiscal policies in a particular case of economic recession: that in which monetary policies prove to be ineffective under a ZLB constraint. Recent works contribute evidence in favour of fiscal policy effectiveness in a ZLB context (see Bodenstein et al. (2009) for open economies, Braun and Waki (2006), and Coenen and Wieland (2003) on Japan's experience in the 1990s, or Christiano et al. (2011)). ${ }^{18}$ The last authors make use of a dynamicstochastic general equilibrium model proposed by Altig et al. (2011) to estimate the value of the multiplier. They prove it is generally below 1 when the central bank's monetary policy follows the Taylor rule, yet it largely exceeds 1 when nominal interest rates does not respond to public-spending increases as it happens in a ZLB context.

Therefore, according to Keynesian models fiscal consolidations in a ZLB context would be contractive, ${ }^{19}$ while expansive fiscal policies would lead to increased GDP, higher marginal costs, and inflationist expectations. With rates stuck at $0 \%$, inflation reduces real interest rates, thus promoting private sector spending, and increasing production again... and so on, until equilibrium is reached for a higher production and inflation levels. Other authors suggest other economic policies in a ZLB context that are alternative to expansionary fiscal policies. Eggertsson and Woodford (2003), for instance, suggest central banks should commit to higher future inflation. Others recommend designing a tax combination to escape ZLB: Feldstein (2003) proposed Japan authorities should increase value-added tax by $1 \%$ each term and simultaneously reduce income taxes equivalently during several years, whereas Correia et al. (2010) also recommended a combination of consumption, income and capital taxes, together with an appropriate monetary policy.

\subsubsection{Consolidation through reduced public spending or increased taxes?}

Another large consensus is in regard the role that public spending and taxes must play in fiscal consolidation. In this sense, consolidations based on public spending cuts are more effective than those based on tax increases. Alesina and Ardagna (1998) show that the composition of this adjustment is a determinant factor of success in a fiscal consolidation.

\footnotetext{
18 Other two previous essays include Christiano (2004) and Eggertsson (2004).

${ }_{19}$ Christiano et al. (2011) explain the mechanism through which fiscal consolidation in a ZLB context would be contractive: for a specific fall in product, marginal costs are reduced and prices fall. With staggered prices, the fall of prices leads agents to anticipate future deflation, so real interest rates increase due to ZLB restriction. This perverse increase in real interest rates rises the desired saving rate, thus increasing the necessary fall in production to reduce desired savings to zero. This scenario reminds that of the thrift paradox (Keynes, 1936; Krugman, 1998).
}

Combining adjustments focused on public spending - preferably cuts in transfers, social expenditures, and wage moderation for public employees - together with monetary devaluation, are more effective and long-lasting than the adjustments based on tax increases, even when the latter are also accompanied by monetary devaluation. Tax increases do not lead to permanent consolidation of public finances, so long-term interest rates would not fall, though agents' confidence and economic growth they would.

Keynesian literature reaches a quite similar conclusion, yet nuanced. Unlike the neoclassical model, public spending cuts are expected to have greater contractive effects than tax increases. Symmetrically, expansionary fiscal policies render greater effectiveness when they are generated by public spending increase than through tax reductions (Alesina and Ardagna, 1998). However, once expansionary fiscal policies have been applied (as it occurred in 2009), a key result of these models (e.g., Corsetti et al., 2009, 2010 ) is that the effectiveness of fiscal policies increases when a correction of these measures in the medium-term by means of spending reversals are anticipated. As explained by Corsetti et al. (2010), the fall of private consumption predicted by the Ricardian equivalence is avoided if the additional spending is initially financed with debt but subsequently offset through a period of below-trend government spending (during the positive stage of the economic cycle). If so, private consumption would behave symmetrically to public spending, rising above trend after a more stable initial stage. The argument that supports this private consumption dynamics is the credibility that a public spending reversal will take place.

\subsubsection{Short- and long-term effects of fiscal consolidation}

There is also wide consensus regarding the fact that the benefits of fiscal consolidation are usually more evident (and feasible) in the long than in the short term, although interpretations regarding adjustment intensity vary among models. Generally speaking, fiscal consolidation procedures involve short-term costs in terms of growth, yet long-term benefits (Hernández de Cos and Thomas, 2012). Short-term contractive effects are evident in the Keynesian model, especially if fiscal consolidation is implemented through spending cuts. On the contrary, neoclassical empirical literature does identify episodes in which fiscal consolidations have non-Keynesian short-term effects (Giavazzi and Pagano, 1990; Alesina et al., 1998; Perotti, 1999). Alesina and Ardagna (1998), and Alesina et al. (2012) argue that the composition of the fiscal adjustment is a key factor, since those based on public spending cuts are less costly in terms of GDP loss than those based on tax increases. ${ }^{20}$

Regarding long-term benefits, Keynesian models subordinate the effectiveness of fiscal consolidations (through public spending reversals) to a subsequent time horizon. Alternatively, the neoclassic approach considers fiscal

\footnotetext{
${ }^{20}$ Nevertheless, Gali et al. (2007) argue that the evidence of non-Keynesian effects shown by Alesina and Ardagna (1998) is no evidence in favour of the neoclassical model because, on average, public spending cuts lead to increases in both production and consumption (p. 235).
} 
adjustments based on public spending cuts are not recessive unlike tax increases, which would lead to long and deep recessions (Alesina et al., 2012). Fiscal consolidation policies based on public spending cuts would also be more effective if accompanied by pertinent structural reforms. Adjustment composition is also relevant: cuts in public investment would have negative long-term effects, while reducing of public employees' remunerations (wages and public employment) would generate greater benefits in the long-term (Hernández de Cos and Thomas, 2012). In any case and whatever approach is put into practice, once fiscal consolidation has managed to reduce the debt-to-DGP ratio, the reduced interest burden would have positive effects on long-term growth.

\subsubsection{The timing of fiscal consolidation}

In this case we cannot talk about univocal evidence, but about a prevailing opinion trend in the last months in favour of the implementation of slow and gradual consolidations. This is visible in the decisions to delay and/or moderate fiscal consolidation requirements of countries such as Spain or Portugal, as well as in academic papers and IMF public statements. For instance, the main conclusion of the recent IMF Working Paper by Batini et al. (2012) states that

(...) smooth and gradual consolidations are to be preferred to frontloaded or aggressive consolidations, especially for economies in recession facing high risk premia on public debt, because sheltering growth is key to the success of fiscal consolidation in these cases. (p. 1)

This view defends that - as long as there is fiscal margin - a growth-based strategy and a smooth fiscal consolidation might be more effective. However, this is more a recent opinion trend than a generalized consensus. For instance, Hernández de Cos and Thomas (2012) support a more vigorous consolidation process, particularly in situations like that of Spain, characterized by high levels of foreign debt and strong dependence on foreign saving. In this situation, public spending cuts might be expected to generate a significant positive effect in terms of ensuring the flow of external funds to the economy and at a lower cost.

Once we have dealt with the issues on which academic consensus has been reached regarding appropriate fiscal consolidation, timing and composition, we shall pose a last question on budget stability of public administrations. If the objective is a balanced budget, is there a public deficit threshold that should not be exceeded in any case? Should this threshold apply in every fiscal year or should we opt for a longer-term control?

Convergence criteria approved in the Maastricht Treaty in 1993 for the adoption of Euro as a common currency imposed, regarding public finances, ${ }^{21}$ a $3 \%$ limit on the

\footnotetext{
${ }^{21}$ Remember that the Maastricht Treaty also approved other three convergence criteria: regarding the inflation rate, which should not exceed $1.5 \%$ average inflation in the three European countries with lower inflation rate; regarding the exchange rate, that the national currency must not be devaluated at least during two consecutive years after joining the European Monetary System; and regarding long-term interest rates, that the risk premium was not to exceed 200 basis points relative to the three countries with lower inflation.
}

annual public deficit-to-GDP ratio and a $60 \%$ limit on the accumulated public debt-to-GDP ratio. More recently, 25 out of the 27 EU member States ${ }^{22}$ approved - with the aim of solving the Euro crisis - the European Fiscal Compact in March 2012. ${ }^{23}$ This Fiscal Treaty settles a new golden rule: while the required public debt ratio is equivalent to that in the Maastricht Treaty (when public debt exceeds 60\% GDP, ratio must be reduced at an average pace of $1 / 20$ every year), the public deficit requirement is more demanding. The norm pursues a budget equilibrium or surplus in public administrations. With this purpose, the lower limit for the annual structural deficit is set at $0.5 \%$ GDP as a medium-term objective. Only when the debt-to-GDP ratio is far below $60 \%$ and risks for long-term sustainability of public finances are low, this limit may reach $1 \%$.

Thus, the Maastricht Treaty imposed a 3\% limit on public deficit, while the current Fiscal Treaty demands $0.5 \%$. However, both figures are not comparable, since there are two important differences in their measurement. ${ }^{24}$ Firstly, the $0.5 \%$ limit in the Fiscal Treaty is a medium-term objective, so member States can only deviate from it temporarily under exceptional circumstances. ${ }^{25}$ The automatic activation of a corrector mechanism is scheduled in case of significant deviations from the medium-term objective or the adjustment path. Secondly, the specified limit corresponds to the annual structural balance ratio on GDP. Annual structural balance of public administrations is understood, according to the Treaty, as the annual cyclically adjusted balance net of oneoff and temporary measures. Structural deficit is therefore referred to the deficit that must be met throughout the economic cycle, allowing deficit in recessive years to be compensated, necessarily, by surplus in growing years.

The concept of structural deficit involves, however, measurement problems. Cyclical components are not observable, but must be estimated by means of highly complex, dynamic, factorial and discrete regime change models (de la Dehesa, 2012b). Thus, it will be difficult to determine the stage of the economic cycle a country is at any moment. Measurements should be made by an independent research centre such as the National Bureau of Economic Research (NBER) in the U.S., and not by the EU Commission. Just another guaranteed controversy... For instance, Andrés and Doménech (2012) estimate the potential growth and structural deficit for Spain, and prove that maintaining the $3 \%$

\footnotetext{
22 All countries except the U.K. and Czech Republic.

${ }^{23}$ Formally known as Treaty on Stability, Coordination and Governance in the Economic and Monetary Union, it was expected to enter into force on January 1, 2013.

24 The $0.5 \%$ golden rule for structural deficit-to-GDP ratio supplements the 3\% limit required by the Maastricht Treaty. However, Verhelst (2012) proves that the norm approved by the Fiscal Treaty will impose much stricter fiscal rigour.

25 Exceptional circumstances mean unusual events out of the control of the affected contracting party that have a significant impact on the financial situation of public administrations, or those periods of serious economic recession according to the revised Stability and Growth Pact, as long as the temporal deviation by the affected contracting party does not put medium-term budgetary sustainability at risk (Art. 3.3.b in the Treaty on Stability, Coordination and Governance in the Economic and Monetary Union; European Council, 2012).
} 
Table 3 GDP growth, GDP deflator, stock of debt and 10-year bond interest rates.

\begin{tabular}{|c|c|c|c|c|c|c|}
\hline & \multicolumn{2}{|c|}{ GDP growth } & \multicolumn{2}{|c|}{ GDP deflator } & \multicolumn{2}{|c|}{ Public debt } \\
\hline & Long term & Short term & Long term & Short term & Stock & $10 y$ rate \\
\hline Spain & $2.18 \%$ & $0.03 \%$ & $3.32 \%$ & $1.73 \%$ & $70 \%$ & $6.58 \%$ \\
\hline Italy & $0.81 \%$ & $-0.73 \%$ & $2.75 \%$ & $2.06 \%$ & $120 \%$ & $5.82 \%$ \\
\hline Ireland & $4.50 \%$ & $-0.70 \%$ & $2.36 \%$ & $-1.19 \%$ & $110 \%$ & $5.91 \%$ \\
\hline Portugal & $1.36 \%$ & $-0.67 \%$ & $2.04 \%$ & $1.45 \%$ & $110 \%$ & $9.89 \%$ \\
\hline Greece & $1.42 \%$ & $-2.57 \%$ & $3.40 \%$ & $2.90 \%$ & $165 \%$ & $24.34 \%$ \\
\hline
\end{tabular}

Source: European Commission (2012), Eurostat and ECB.

public deficit-to-GDP objective in the Stability Programme ${ }^{26}$ by 2013 , with a $0.6 \%$ economic growth forecasted that year, would be equivalent to imposing a balanced structural deficit seven years before the expected deadline in the Budgetary Stability Pact!

Finally, an even more demanding norm is to be implemented in Spain after the Budgetary Stability Pact (Ley de Estabilidad Presupuestaria, BOE; April 30, 2012) was approved, setting up the zero-deficit objective:

no public administration can incur structural deficit, defined as cycle-adjusted deficit, including exceptional and temporal measures,

within a time horizon to achieve it by 2020 . Some authors (Verhelst, 2012; Whelan, 2012) point out that the European and Spanish norms will impose stronger restrictions to the use of fiscal policies as measures for economic stabilization, although there is no consensus regarding this issue, since there is no consensus on the goodness of fiscal policy either. In any case, what does not seem reasonable is to account long-term public investments in structural deficit calculations. ${ }^{27}$ Finally, it seems to be a growing consensus on the idea that the Fiscal Treaty should also be accompanied by a fiscal union - including a European Treasury that issues public debt common to all States known as Eurobonds - as well as bank union that empowers the ECB as a true lender of last resort.

\section{Growth, inflation, monetary policy, and the sustainability of public debt}

To better understand the growth versus austerity dilemma we examine the relationship among ability to deleverage, growth and inflation by using data from the GIPSI countries. Then we compare our results with findings of the recent analysis by the IMF (IMF, 2012d) regarding several historical

\footnotetext{
26 Remember that they were subsequently softened.

27 As explained by de la Dehesa (2012a,b), the golden rule should not be named that way because it has nothing to do with the socalled golden rule introduced by Alexander Hamilton, Secretary of the American Treasury, in 1790. According to this rule, the Federal Treasury assumed the debt of all member States as long as a simple and effective rule was met: debt had to be aimed for investment purposes, not for financing current expenses. That is, this golden rule allows States to have a deficit as long as it has been completely invested and it holds for more than two consecutive years, unless in exceptional situations.
}

episodes during the 20th century where public debt rose above $100 \%$ of GDP. To analyze and understand the factors that determine the sustainability of the public debt, we apply the methodology of the Barometer of public debt by Kiel Institute (Bencek and Klodt, 2011). We first examine in detail the case of Spain and then we compare the results with those of the rest of the GIPSI countries.

Bencek and Klodt (2011) empirical assessment concludes that it is extremely difficult for a country to prevent its debt from increasing infinitely when the necessary PSR reaches a critical level of more than $5 \%$. Most countries that exceeded this level for some time eventually needed outside help to deal with their debt. What we do is to test whether debt would reach or not that threshold in different macroeconomic scenarios. First, we combine high and low real economic growth with low and moderate inflation (in terms of GDP deflator), so we get four scenarios for each country. Simultaneously, for each one of them we analyze three scenarios for the stock of debt (namely, today's level, a 50\% increase, and twice the stock) and other three scenarios for the cost of debt (namely, today's level, 28 . $8 \%$ and 12\%). In the aggregate, 36 scenarios for each country are then considered.

In contrast with Bencek and Klodt (2011), we use data of historic GDP growth and deflator, stock of public debt and market interest rates, and then the different scenarios of high and low growth, inflation, etc. are projected using those historic rates. We believe these assumptions are more realistic than using the same average projections for all countries, since their current situation is very different. Table 3 below summarizes data regarding annual average growth in real terms and GDP deflator, ${ }^{29}$ both for a long term (last 20 years average) and short term (last 6 years average), stock of public debt and interest rates of public debt at secondary markets. ${ }^{30}$

Based on this historic data, the projections for each of the different scenarios are summarized in Table 4.

Generally speaking, we set a high growth context by considering each country would grow in the future at the mean

\footnotetext{
${ }^{28}$ For Portugal and Greece, where interest rates are similar or superior to stress levels we have assumed ( 8 and $12 \%$, respectively), we only conduct the analysis for the stress levels.

29 We use growth data by the European Commission (2012) and GDP deflator by Eurostat.

30 Debt data corresponds to December 2011, using Eurostat database, and interest rates correspond to 10-year bonds in secondary markets, according to ECB data by the end of August 2012.
} 


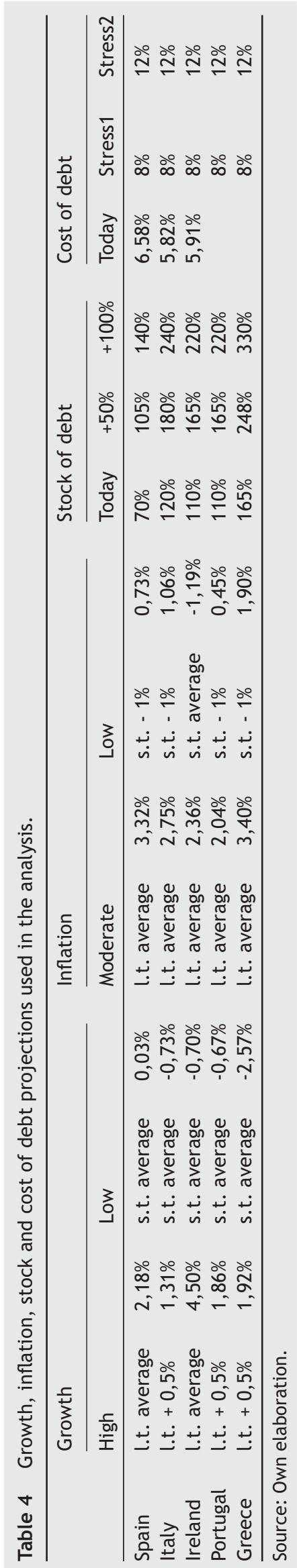

historic real economic growth of the last 20 years, while a low growth scenario corresponds to the mean historic real growth of the last 6 years. ${ }^{31}$ Besides, we set a moderate inflation scenario using the historical average of the GDP deflator for the last 20 years, and for a low inflation scenario using the average of the last 6 years minus $1 \% .{ }^{32}$ Finally, we analyze three scenarios for the stock of debt (today's level, a $50 \%$ increase, and twice the stock) and other three scenarios for the cost of debt (today's cost, $8 \%$ and 12\%). The results for the case of Spain are recorded in Table 5.

Table 5 is useful to understand the effect of GDP growth in nominal terms over the sustainability of public debt. Different contexts are denoted by different colour (black text indicates that the PSR required to prevent public debt to become explosive is below the $5 \%$ threshold; green text, that it is at about that 5\%; and red text stands for unsustainable levels where the required PSR is above $5 \%$ ). Hence, in the high growth-moderate inflation context (upper right corner), the Spanish public debt would be sustainable in seven of the nine scenarios. This includes assuming twice the stock of debt and a cost of debt well above $8 \%$. For this to be valid, the Spanish economy would have to grow at a $5.5 \%$ annual nominal rate, ${ }^{33}$ which requires being able to grow at a pace equivalent to the last 20 years average, while inflation should be above $3 \%$.

The cost of debt Spain is paying at the markets today ${ }^{34}$ would ensure the sustainability of twice the stock of debt (up to $140 \%$ of GDP) if either the economic growth or the inflation are high enough (see upper left and lower right corners in Table 5), so nominal growth stands around 3-3.5\%. However, if the Spanish economy remains stagnant and facing the threat of deflation (lower left corner), then nominal GDP growth would not reach $1 \%$ and the government could not issue more debt: a stock of debt of $105 \%$ of GDP would require paying $5.5 \%$ or less for debt to be sustainable.

In brief, Spanish debt is sustainable in the present context - comparable to the low growth-moderate inflation scenario ${ }^{35}$ (see shaded box in Table 5) - with a required PSR of $2.2 \%$. This could admit even higher debt-to-GDP ratios

\footnotetext{
31 Exceptions are for the 'high growth scenario' of Italy, Greece and Portugal. Historical data (see Table 3) shows that for these countries one fundamental macroeconomic problem is that of growth particularly for Italy, which experienced a real growth of less than $1 \%$ during the last 20 years. That is why we correct this by assuming a 'high growth scenario' to be the one where these countries are able to grow at $0.5 \%$ above their historical mean.

32 The only exception here is Ireland, for which we use its historical average during the last 6 years given it is the only country in the analysis that is recently showing signs of deflation.

33 Note that, for the sake of simplicity and better understanding, we have added real growth and inflation in order to obtain nominal growth data. This is obviously just an approximation: for example, for a real GDP growth of $2.18 \%$ and an inflation rate of $3.32 \%$ we use a nominal rate for the 'high growth-high inflation' scenario of $5.50 \%$, when the exact value should be $5.57 \%$.

34 About $6.5 \%$ for 10 -year bonds by August 2012 .

35 We are considering the current situation of the Spanish economy as equivalent to a context of low growth and high inflation (over $3 \%$ ). This statement must be qualified: 2012 forecasts predict a GDP contraction of around $1.5 \%$, well below the zero growth we use at this scenario.
} 
Table 5 Results for Spain.

\begin{tabular}{|c|c|c|c|c|c|c|c|c|}
\hline & \multicolumn{4}{|c|}{ Low inflation } & \multicolumn{4}{|c|}{ Moderate inflation } \\
\hline & & Debt/GDP & $i$ & $g$ & & Debt/GDP & $i$ & $g$ \\
\hline \multirow[t]{10}{*}{ HIGH GROWTH } & $2,5 \%$ & $70 \%$ & $6,50 \%$ & $2,91 \%$ & $0,7 \%$ & $70 \%$ & $6,50 \%$ & $5,50 \%$ \\
\hline & $3,6 \%$ & $70 \%$ & $8,00 \%$ & $2,91 \%$ & $1,8 \%$ & $70 \%$ & $8,00 \%$ & $5,50 \%$ \\
\hline & $6,4 \%$ & $70 \%$ & $12,00 \%$ & $2,91 \%$ & $4,6 \%$ & $70 \%$ & $12,00 \%$ & $5,50 \%$ \\
\hline & $3,8 \%$ & $105 \%$ & $6,50 \%$ & $2,91 \%$ & $1,1 \%$ & $105 \%$ & $6,50 \%$ & $5,50 \%$ \\
\hline & $5,3 \%$ & $105 \%$ & $8,00 \%$ & $2,91 \%$ & $2,6 \%$ & $105 \%$ & $8,00 \%$ & $5,50 \%$ \\
\hline & $9,5 \%$ & $105 \%$ & $12,00 \%$ & $2,91 \%$ & $6,8 \%$ & $105 \%$ & $12,00 \%$ & $5,50 \%$ \\
\hline & $5,0 \%$ & $140 \%$ & $6,50 \%$ & $2,91 \%$ & $1,4 \%$ & $140 \%$ & $6,50 \%$ & $5,50 \%$ \\
\hline & $7,1 \%$ & $140 \%$ & $8,00 \%$ & $2,91 \%$ & $3,5 \%$ & $140 \%$ & $8,00 \%$ & $5,50 \%$ \\
\hline & $12,7 \%$ & $140 \%$ & $12,00 \%$ & $2,91 \%$ & $9,1 \%$ & $140 \%$ & $12,00 \%$ & $5,50 \%$ \\
\hline & & Debt/GDP & $i$ & $g$ & & Debt/GDP & $i$ & $g$ \\
\hline \multirow[t]{9}{*}{ LOW GROWTH } & $4,0 \%$ & $70 \%$ & $6,50 \%$ & $0,76 \%$ & $2,2 \%$ & $70 \%$ & $6,50 \%$ & $3,35 \%$ \\
\hline & $5,1 \%$ & $70 \%$ & $8,00 \%$ & $0,76 \%$ & $3,3 \%$ & $70 \%$ & $8,00 \%$ & $3,35 \%$ \\
\hline & $7,9 \%$ & $70 \%$ & $12,00 \%$ & $0,76 \%$ & $6,1 \%$ & $70 \%$ & $12,00 \%$ & $3,35 \%$ \\
\hline & $5,0 \%$ & $105 \%$ & $5,50 \%$ & $0,76 \%$ & $3,3 \%$ & $105 \%$ & $6,50 \%$ & $3,35 \%$ \\
\hline & $7,6 \%$ & $105 \%$ & $8,00 \%$ & $0,76 \%$ & $4,9 \%$ & $105 \%$ & $8,00 \%$ & $3,35 \%$ \\
\hline & $11,8 \%$ & $105 \%$ & $12,00 \%$ & $0,76 \%$ & $9,1 \%$ & $105 \%$ & $12,00 \%$ & $3,35 \%$ \\
\hline & $5,0 \%$ & $140 \%$ & $4,30 \%$ & $0,76 \%$ & $4,4 \%$ & $140 \%$ & $6,50 \%$ & $3,35 \%$ \\
\hline & $10,1 \%$ & $140 \%$ & $8,00 \%$ & $0,76 \%$ & $6,5 \%$ & $140 \%$ & $8,00 \%$ & $3,35 \%$ \\
\hline & $15,7 \%$ & $140 \%$ & $12,00 \%$ & $0,76 \%$ & $12,1 \%$ & $140 \%$ & $12,00 \%$ & $3,35 \%$ \\
\hline
\end{tabular}

Source: Own elaboration.

than today, as long as the economy does not fall in a scenario of stagflation and debt cost does not soars above $8 \%$.

Spain exhibits the best profile among the countries analyzed. The situation is even better than for Italy or Ireland, countries that, however, are required lower returns in the debt markets (see Tables 6 and 7).

This methodology offers a simple interpretation of how economic growth and inflation facilitate debt sustainability. In the current situation (shaded boxes in Tables 6-9), only Italian debt would be sustainable, and barely. Italy required PSR would be almost 5\%, because Italian shows the highest debt-to-GDP ratio of the countries analyzed, only below Greece.

In turn, Ireland needs to avoid the deflation that is facing since 2008, in order for current market rates (now below 6\%) to be enough to ensure the sustainability of a $100 \%$ debt-toGDP ratio. Note we are using rates at secondary markets: while this is a good approach to analyze whether countries would be able to finance themselves at the rates required by the markets, these rates are not a good proxy neither for Irish, Portuguese nor Greek current public finances, since they have been already rescued.

On the other hand, results in Tables 8 and 9 indicate that the situation is clearly unsustainable for Greece and Portugal, though Portugal has improved with the recent fall of interest rates paid for its debt.

From this analysis two conclusions are in order. First, the high levels of debt already accumulated (110\% by Ireland and Portugal, $120 \%$ by Italy and $165 \%$ by Greece) are untenable in a low growth scenario: all the lower left corners are in red, with required interest rates at levels unattainable (Italy and Portugal would need to pay only $2-4 \%$, between 4 and $5 \%$ would Ireland endure as long as it does not fall into deflation, while Greece would require an impossible $1-3 \%$ level). Being able to combine fiscal consolidation and economic measures that enhances both their real and economic growth is now essential for these four countries. ${ }^{36}$ Still, only Ireland would be in a clearly solvent position in a high growth-moderate inflation scenario: Italy, Portugal and particularly Greece could hardly endure higher levels of debt even if they grow. Growth is urgent for these countries; deleveraging, unavoidable. The second conclusion is observable when we make a solvency ranking based on the ability of the five countries in the analysis to pay their debts, according to their debt-toGDP ratios, growth, inflation and market rates. The ranking (from more to less ability to pay) would be Spain, Italy, Ireland (quite close these two countries), Portugal and Greece.

Fig. 3 shows two combinations of nominal growth and required PSR for each country. The graph on the left is the current low growth-moderate inflation scenario most countries are facing; we may clearly see the correlation between the higher the nominal growth the lower the required PSR. On the right graph of Fig. 3 we summarize the same relationship, but assuming countries were able to set

36 That is why it is not a nice presage to notice that low growth and competitiveness are endemic indeed in economies like Italy $(0.8 \%$ average growth during the last two decades), Portugal $(1.36 \%)$ or Greece (1.42\%). 
Table 6 Results for Italy.

\begin{tabular}{|c|c|c|c|c|c|c|c|c|}
\hline & \multicolumn{4}{|c|}{ Low inflation } & \multicolumn{4}{|c|}{ Moderate inflation } \\
\hline & & Debt/GDP & i & g & & Debt/GDP & $i$ & $\mathrm{~g}$ \\
\hline \multirow[t]{10}{*}{ HIGH GROWTH } & $4,1 \%$ & $120 \%$ & $5,80 \%$ & $2,37 \%$ & $2,1 \%$ & $120 \%$ & $5,80 \%$ & $4,06 \%$ \\
\hline & $6,8 \%$ & $120 \%$ & $8,00 \%$ & $2,37 \%$ & $4,7 \%$ & $120 \%$ & $8,00 \%$ & $4,06 \%$ \\
\hline & $11,6 \%$ & $120 \%$ & $12,00 \%$ & $2,37 \%$ & $9,5 \%$ & $120 \%$ & $12,00 \%$ & $4,06 \%$ \\
\hline & $6,2 \%$ & $180 \%$ & $5,80 \%$ & $2,37 \%$ & $3,1 \%$ & $180 \%$ & $5,80 \%$ & $4,06 \%$ \\
\hline & $10,1 \%$ & $180 \%$ & $8,00 \%$ & $2,37 \%$ & $7,1 \%$ & $180 \%$ & $8,00 \%$ & $4,06 \%$ \\
\hline & $17,3 \%$ & $180 \%$ & $12,00 \%$ & $2,37 \%$ & $14,3 \%$ & $180 \%$ & $12,00 \%$ & $4,06 \%$ \\
\hline & $8,2 \%$ & $240 \%$ & $5,80 \%$ & $2,37 \%$ & $4,2 \%$ & $240 \%$ & $5,80 \%$ & $4,06 \%$ \\
\hline & $13,5 \%$ & $240 \%$ & $8,00 \%$ & $2,37 \%$ & $9,5 \%$ & $240 \%$ & $8,00 \%$ & $4,06 \%$ \\
\hline & $23,1 \%$ & $240 \%$ & $12,00 \%$ & $2,37 \%$ & $19,1 \%$ & $240 \%$ & $12,00 \%$ & $4,06 \%$ \\
\hline & & Debt/GDP & $i$ & $g$ & & Debt/GDP & $i$ & $g$ \\
\hline \multirow[t]{9}{*}{ LOW GROWTH } & $5,0 \%$ & $120 \%$ & $4,50 \%$ & $0,33 \%$ & $4,5 \%$ & $120 \%$ & $5,80 \%$ & $2,02 \%$ \\
\hline & $9,2 \%$ & $120 \%$ & $8,00 \%$ & $0,33 \%$ & $7,2 \%$ & $120 \%$ & $8,00 \%$ & $2,02 \%$ \\
\hline & $14,0 \%$ & $120 \%$ & $12,00 \%$ & $0,33 \%$ & $12,0 \%$ & $120 \%$ & $12,00 \%$ & $2,02 \%$ \\
\hline & $5,0 \%$ & $180 \%$ & $3,10 \%$ & $0,33 \%$ & $5,0 \%$ & $180 \%$ & $4,80 \%$ & $2,02 \%$ \\
\hline & $13,8 \%$ & $180 \%$ & $8,00 \%$ & $0,33 \%$ & $10,8 \%$ & $180 \%$ & $8,00 \%$ & $2,02 \%$ \\
\hline & $21,0 \%$ & $180 \%$ & $12,00 \%$ & $0,33 \%$ & $18,0 \%$ & $180 \%$ & $12,00 \%$ & $2,02 \%$ \\
\hline & $5,0 \%$ & $240 \%$ & $2,40 \%$ & $0,33 \%$ & $4,8 \%$ & $240 \%$ & $4,00 \%$ & $2,02 \%$ \\
\hline & $18,4 \%$ & $240 \%$ & $8,00 \%$ & $0,33 \%$ & $14,4 \%$ & $240 \%$ & $8,00 \%$ & $2,02 \%$ \\
\hline & $28,0 \%$ & $240 \%$ & $12,00 \%$ & $0,33 \%$ & $24,0 \%$ & $240 \%$ & $12,00 \%$ & $2,02 \%$ \\
\hline
\end{tabular}

Source: Own elaboration.
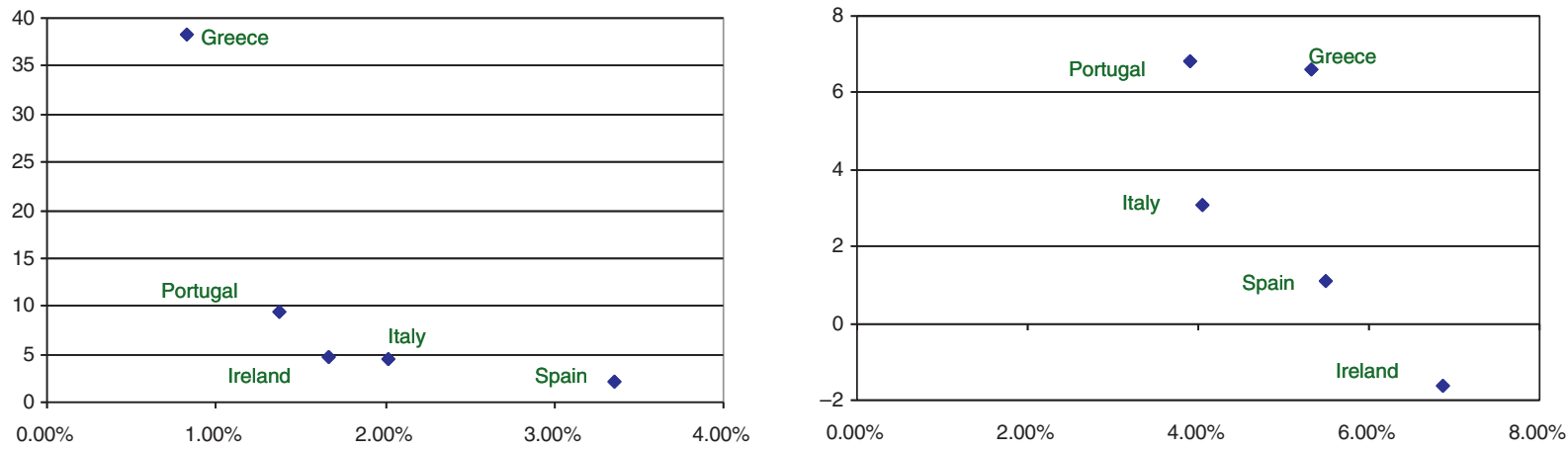

Figure 3 Two scenarios for GDP nominal growth and required PSR.

Source: Own elaboration.

themselves at the high growth-moderate inflation scenario, combined with a $50 \%$ higher stock of debt. ${ }^{37}$ We may see how they have improved - please note the different scale we used in the left and in the right graphs of Fig. 3.

The better profile for the Spanish debt in our analysis is inconsistent with the higher cost of debt markets are requir-

\footnotetext{
37 Data for Spain, Italy and Ireland in the right hand side graph use the same cost of debt as they are paying today. Instead, for Portugal and $G$ reece we assume they would be able to improve their financing conditions to an $8 \%$ cost of debt.
}

ing compared to Italy or, in recent times, Ireland. We see a double reason for this. On one hand, market concerns boosted when, May 9, 2012, Bankia was nationalized and then it was publicly announced that it would require capital injections of 23 billion euros. Later, June 9, the Spanish government announced it had solicited financial aid from the EU, up to 100 billion euros to be used in the rescue of the banking sector. This shows the sustainability of the public debt depends not only on the stock of public debt accumulated, but also on the stock of private debt when it is the public sector who ends up guaranteeing such private 
Table 7 Results for Ireland.

\begin{tabular}{|c|c|c|c|c|c|c|c|c|}
\hline & \multicolumn{4}{|c|}{ Low inflation } & \multicolumn{4}{|c|}{ Moderate inflation } \\
\hline & & Debt/GDP & $i$ & $g$ & & Debt/GDP & $i$ & $g$ \\
\hline \multirow[t]{10}{*}{ HIGH GROWTH } & $2,8 \%$ & $110 \%$ & $5,90 \%$ & $3,31 \%$ & $-1,1 \%$ & $110 \%$ & $5,90 \%$ & $6,86 \%$ \\
\hline & $5,2 \%$ & $110 \%$ & $8,00 \%$ & $3,31 \%$ & $1,3 \%$ & $110 \%$ & $8,00 \%$ & $6,86 \%$ \\
\hline & $9,6 \%$ & $110 \%$ & $12,00 \%$ & $3,31 \%$ & $5,7 \%$ & $110 \%$ & $12,00 \%$ & $6,86 \%$ \\
\hline & $4,3 \%$ & $165 \%$ & $5,90 \%$ & $3,31 \%$ & $-1,6 \%$ & $165 \%$ & $5,90 \%$ & $6,86 \%$ \\
\hline & $7,7 \%$ & $165 \%$ & $8,00 \%$ & $3,31 \%$ & $1,9 \%$ & $165 \%$ & $8,00 \%$ & $6,86 \%$ \\
\hline & $14,3 \%$ & $165 \%$ & $12,00 \%$ & $3,31 \%$ & $8,5 \%$ & $165 \%$ & $12,00 \%$ & $6,86 \%$ \\
\hline & $5,7 \%$ & $220 \%$ & $5,90 \%$ & $3,31 \%$ & $-2,1 \%$ & $220 \%$ & $5,90 \%$ & $6,86 \%$ \\
\hline & $10,3 \%$ & $220 \%$ & $8,00 \%$ & $3,31 \%$ & $2,5 \%$ & $220 \%$ & $8,00 \%$ & $6,86 \%$ \\
\hline & $19,1 \%$ & $220 \%$ & $12,00 \%$ & $3,31 \%$ & $11,3 \%$ & $220 \%$ & $12,00 \%$ & $6,86 \%$ \\
\hline & & Debt/GDP & $i$ & $g$ & & Debt/GDP & $i$ & $g$ \\
\hline \multirow[t]{9}{*}{ LOW GROWTH } & $8,6 \%$ & $110 \%$ & $5,90 \%$ & $-1,89 \%$ & $4,7 \%$ & $110 \%$ & $5,90 \%$ & $1,66 \%$ \\
\hline & $10,9 \%$ & $110 \%$ & $8,00 \%$ & $-1,89 \%$ & $7,0 \%$ & $110 \%$ & $8,00 \%$ & $1,66 \%$ \\
\hline & $15,3 \%$ & $110 \%$ & $12,00 \%$ & $-1,89 \%$ & $11,4 \%$ & $110 \%$ & $12,00 \%$ & $1,66 \%$ \\
\hline & $5,1 \%$ & $165 \%$ & $1,20 \%$ & $-1,89 \%$ & $5,0 \%$ & $165 \%$ & $4,70 \%$ & $1,66 \%$ \\
\hline & $16,3 \%$ & $165 \%$ & $8,00 \%$ & $-1,89 \%$ & $10,5 \%$ & $165 \%$ & $8,00 \%$ & $1,66 \%$ \\
\hline & $22,9 \%$ & $165 \%$ & $12,00 \%$ & $-1,89 \%$ & $17,1 \%$ & $165 \%$ & $12,00 \%$ & $1,66 \%$ \\
\hline & $5,0 \%$ & $220 \%$ & $0,40 \%$ & $-1,89 \%$ & $5,1 \%$ & $220 \%$ & $4,00 \%$ & $1,66 \%$ \\
\hline & $21,8 \%$ & $220 \%$ & $8,00 \%$ & $-1,89 \%$ & $13,9 \%$ & $220 \%$ & $8,00 \%$ & $1,66 \%$ \\
\hline & $30,6 \%$ & $220 \%$ & $12,00 \%$ & $-1,89 \%$ & $22,7 \%$ & $220 \%$ & $12,00 \%$ & $1,66 \%$ \\
\hline
\end{tabular}

Source: Own elaboration.

debt - particularly from the banking sector. ${ }^{38}$ On the other hand, Spain is facing a problem of credibility to balance its public finances. Bencek and Klodt (2011)'s methodology is based on empirical evidence about the 5\% PSR threshold beyond which it becomes extremely difficult to avoid debt growth from becoming explosive. However, a $5 \%$ primary surplus is certainly a very demanding level to achieve: Italy, for instance, has been able to generate primary surpluses during the last decades, what improves its credibility to the eyes of the market ${ }^{39}$; Spain, on the contrary (see Fig. 4), could not improve its public deficit after two years of austerity measures $(-9.3 \%$ in 2010 and $-9.4 \%$ in 2011 according to the most recent update). Primary deficit was $-6.1 \%$ in 2011 , and it was expected to be only at -3\% in 2012 even if the objectives set by the European authorities are fulfilled.

To summarize, our analysis suggests that governments could have higher ability to make public debt sustainable in a context of high growth and moderate inflation. Sustain-

\footnotetext{
38 Indeed, the last IMF fiscal monitor available at the time of writing this article (July 2012, IMF, 2012b) forecasted an increase in the debt-to-GDP ratio of Spain from 68.5\% in 2011 to $90.3 \%$ in 2012. This forecast corrected the previous estimation in April (IMF, 2012a) by more than 11 percentage points - a rise that would correspond, largely, with the debt assumed after the banking sector bailout.

39 Recall the results in Table 1, where Italy exhibits the best result after Germany in terms of the Barometer of debt. This was a result mainly of Italian ability to generate positive PSRs.
}

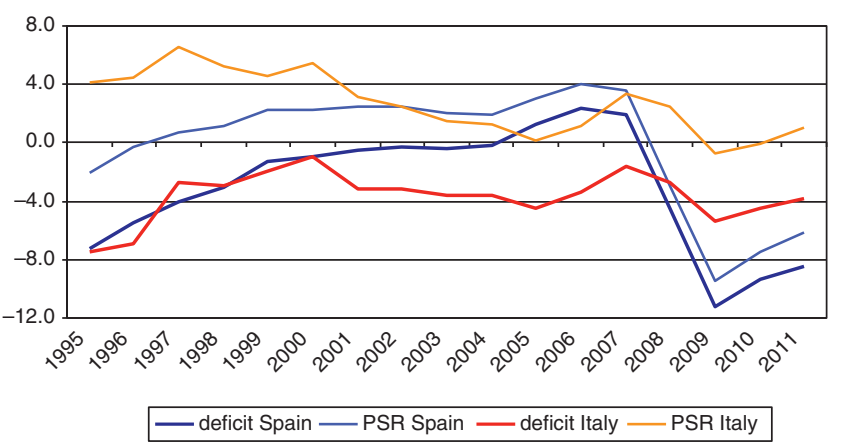

Figure 4 Public deficit and primary surplus (PSR) of Italy and Spain.

Source: ECB Statistical Data Warehouse.

ability also depends on the credibility markets judge about the ability of governments to balance their budget, as well as on the effect that private sector debt might have over public finances. Growth, inflation, credibility and deleverage of private sector would be, henceforth, desirable outcomes in order to guarantee the sustainability of public debt.

However, this is not the end of the debate. Indeed, it is only the beginning. On one hand, the necessity of a higher growth takes us back to the debate about how to achieve it: trough expansionary fiscal policies that make use of a high government spending multiplier?; through austerity measures that increase the market confidence? On the other 
Table 8 Results for Portugal.

\begin{tabular}{|c|c|c|c|c|c|c|c|c|}
\hline & \multicolumn{4}{|c|}{ Low inflation } & \multicolumn{4}{|c|}{ Moderate inflation } \\
\hline & & Debt/GDP & $i$ & $g$ & & Debt/GDP & $i$ & $g$ \\
\hline \multirow[t]{10}{*}{ HIGH GROWTH } & $5,2 \%$ & $110 \%$ & $7,00 \%$ & $2,31 \%$ & & & & \\
\hline & $6,3 \%$ & $110 \%$ & $8,00 \%$ & $2,31 \%$ & $4,5 \%$ & $110 \%$ & $8,00 \%$ & $3,90 \%$ \\
\hline & $10,7 \%$ & $110 \%$ & $12,00 \%$ & $2,31 \%$ & $8,9 \%$ & $110 \%$ & $12,00 \%$ & $3,90 \%$ \\
\hline & $4,9 \%$ & $165 \%$ & $5,30 \%$ & $2,31 \%$ & $5,1 \%$ & $165 \%$ & $7,00 \%$ & $3,90 \%$ \\
\hline & $9,4 \%$ & $165 \%$ & $8,00 \%$ & $2,31 \%$ & $6,8 \%$ & $165 \%$ & $8,00 \%$ & $3,90 \%$ \\
\hline & $16,0 \%$ & $165 \%$ & $12,00 \%$ & $2,31 \%$ & $13,4 \%$ & $165 \%$ & $12,00 \%$ & $3,90 \%$ \\
\hline & $4,8 \%$ & $220 \%$ & $4,50 \%$ & $2,31 \%$ & $5,1 \%$ & $220 \%$ & $6,20 \%$ & $3,90 \%$ \\
\hline & $12,5 \%$ & $220 \%$ & $8,00 \%$ & $2,31 \%$ & $9,0 \%$ & $220 \%$ & $8,00 \%$ & $3,90 \%$ \\
\hline & $21,3 \%$ & $220 \%$ & $12,00 \%$ & $2,31 \%$ & $17,8 \%$ & $220 \%$ & $12,00 \%$ & $3,90 \%$ \\
\hline & & Debt/GDP & $i$ & $g$ & & Debt/GDP & $i$ & $g$ \\
\hline \multirow[t]{9}{*}{ LOW GROWTH } & $5,1 \%$ & $110 \%$ & $4,40 \%$ & $-0,22 \%$ & $4,9 \%$ & $110 \%$ & $5,80 \%$ & $1,37 \%$ \\
\hline & $9,0 \%$ & $110 \%$ & $8,00 \%$ & $-0,22 \%$ & $7,3 \%$ & $110 \%$ & $8,00 \%$ & $1,37 \%$ \\
\hline & $13,4 \%$ & $110 \%$ & $12,00 \%$ & $-0,22 \%$ & $9,4 \%$ & $110 \%$ & $9,90 \%$ & $1,37 \%$ \\
\hline & $5,0 \%$ & $165 \%$ & $2,80 \%$ & $-0,22 \%$ & $5,0 \%$ & $165 \%$ & $4,40 \%$ & $1,37 \%$ \\
\hline & $13,6 \%$ & $165 \%$ & $8,00 \%$ & $-0,22 \%$ & $10,9 \%$ & $165 \%$ & $8,00 \%$ & $1,37 \%$ \\
\hline & $20,2 \%$ & $165 \%$ & $12,00 \%$ & $-0,22 \%$ & $17,5 \%$ & $165 \%$ & $12,00 \%$ & $1,37 \%$ \\
\hline & $4,9 \%$ & $220 \%$ & $2,00 \%$ & $-0,22 \%$ & $4,9 \%$ & $220 \%$ & $3,60 \%$ & $1,37 \%$ \\
\hline & $18,1 \%$ & $220 \%$ & $8,00 \%$ & $-0,22 \%$ & $14,6 \%$ & $220 \%$ & $8,00 \%$ & $1,37 \%$ \\
\hline & $26,9 \%$ & $220 \%$ & $12,00 \%$ & $-0,22 \%$ & $23,4 \%$ & $220 \%$ & $12,00 \%$ & $1,37 \%$ \\
\hline
\end{tabular}

Source: Own elaboration.

hand, the favourable effect of a moderate inflation has the support of some economists (the Keynesian literature, basically), but only a negative answer from European authorities and some other economists, who consider that the potential damages of inflation (lower credibility of monetary policy, lower capital inflows in the future, the possibility of a inflationary spiral, etc.) are more important than its benefits. In any case, this is an approach more accepted in Europe than in other regions, since as it is well known the FED and other central banks do have a double macroeconomic objective of stable inflation and higher growth. Besides, we should not forget it is true that capital does not like inflation, since it erodes its purchasing power, but scarier would be the possibility of a default to occur - a potential scenario if the explosiveness of public debt is not avoided.

\section{Comparing our results with those of the IMF's The good, the bad and the ugly}

The recent IMF's World Economic Outlook (IMF, 2012d) identifies all advanced economy episodes ${ }^{40}$ since 1875 that begin

\footnotetext{
40 Emerging markets and developing economies were not included in the analysis for comparison purposes: their public debt was mostly external and denominated in foreign currency, while their economic structures and institutions can differ substantially.
}

when gross public debt rises above $100 \%$ of GDP, ${ }^{41}$ from Italy 1876 to Japan 1997. The analysis of 26 episodes during the 20th century where the debt-to-GDP ratios rose above the $100 \%$ threshold aims to see what happened next when different policies were implemented in order to deleverage public finances, some of them were successful while others were not able to prevent public debt from continuing to increase. Beyond this analysis, six case studies out of those 26 episodes were also discussed in detail. These in-depth case studies cover a full range of policy approaches and economic outcomes, allowing us to compare the relative effectiveness of different policies implemented.

The analysis shows that the range of experiences is broad, including cases where debt was reduced by $60 \%$ but also where it increased $90 \%$. The median debt ratio does tend to fall, but only at a moderate pace: after 15 years, the median debt-to-GDP ratio is only about 10 percentage points lower. Additionally, this pattern of falling median debt ratios only holds for high levels of debt; the same analysis using a $60 \%$ threshold evidences the median debt level shows no tendency to decrease (with the average debt level being actually higher).

\footnotetext{
41 The $100 \%$ threshold is used because of three reasons: because its relevance today, because it is a relatively high historical threshold (only 15\% if the observations in IMF's database were above that (evel), and because the analysis shows authorities do not tend to exert downward pressure on debt until it reaches that threshold.
} 
Table 9 Results for Greece.

\begin{tabular}{|c|c|c|c|c|c|c|c|c|}
\hline & \multicolumn{4}{|c|}{ Low inflation } & \multicolumn{4}{|c|}{ Moderate inflation } \\
\hline & & Debt/GDP & $i$ & $g$ & & Debt/GDP & $i$ & $g$ \\
\hline \multirow[t]{10}{*}{ HIGH GROWTH } & $5,2 \%$ & $165 \%$ & $7,00 \%$ & $3,82 \%$ & $4,6 \%$ & $145 \%$ & $8,00 \%$ & $4,81 \%$ \\
\hline & $6,9 \%$ & $165 \%$ & $8,00 \%$ & $3,82 \%$ & $4,4 \%$ & $165 \%$ & $8,00 \%$ & $5,32 \%$ \\
\hline & $13,5 \%$ & $165 \%$ & $12,00 \%$ & $3,82 \%$ & $11,0 \%$ & $165 \%$ & $12,00 \%$ & $5,32 \%$ \\
\hline & $4,9 \%$ & $248 \%$ & $5,80 \%$ & $3,82 \%$ & $5,0 \%$ & $218 \%$ & $7,60 \%$ & $5,32 \%$ \\
\hline & $10,3 \%$ & $248 \%$ & $8,00 \%$ & $3,82 \%$ & $6,6 \%$ & $248 \%$ & $8,00 \%$ & $5,32 \%$ \\
\hline & $20,2 \%$ & $248 \%$ & $12,00 \%$ & $3,82 \%$ & $16,5 \%$ & $248 \%$ & $12,00 \%$ & $5,32 \%$ \\
\hline & $4,9 \%$ & $330 \%$ & $5,30 \%$ & $3,82 \%$ & $4,9 \%$ & $290 \%$ & $7,00 \%$ & $5,32 \%$ \\
\hline & $13,8 \%$ & $330 \%$ & $8,00 \%$ & $3,82 \%$ & $8,8 \%$ & $330 \%$ & $8,00 \%$ & $5,32 \%$ \\
\hline & $27,0 \%$ & $330 \%$ & $12,00 \%$ & $3,82 \%$ & $22,0 \%$ & $330 \%$ & $12,00 \%$ & $5,32 \%$ \\
\hline & & Debt/GDP & $i$ & $g$ & & Debt/GDP & $i$ & $g$ \\
\hline \multirow[t]{9}{*}{ LOW GROWTH } & $5,1 \%$ & $165 \%$ & $2,40 \%$ & $-0,67 \%$ & $4,9 \%$ & $165 \%$ & $3,80 \%$ & $0,83 \%$ \\
\hline & $14,3 \%$ & $165 \%$ & $8,00 \%$ & $-0,67 \%$ & $11,8 \%$ & $165 \%$ & $8,00 \%$ & $0,83 \%$ \\
\hline & $20,9 \%$ & $165 \%$ & $12,00 \%$ & $-0,67 \%$ & $38,2 \%$ & $165 \%$ & $24,00 \%$ & $0,83 \%$ \\
\hline & $5,1 \%$ & $248 \%$ & $1,40 \%$ & $-0,67 \%$ & $4,9 \%$ & $248 \%$ & $2,80 \%$ & $0,83 \%$ \\
\hline & $21,5 \%$ & $248 \%$ & $8,00 \%$ & $-0,67 \%$ & $17,7 \%$ & $248 \%$ & $8,00 \%$ & $0,83 \%$ \\
\hline & $31,4 \%$ & $248 \%$ & $12,00 \%$ & $-0,67 \%$ & $27,6 \%$ & $248 \%$ & $12,00 \%$ & $0,83 \%$ \\
\hline & $4,9 \%$ & $330 \%$ & $0,80 \%$ & $-0,67 \%$ & $4,9 \%$ & $330 \%$ & $2,30 \%$ & $0,83 \%$ \\
\hline & $28,6 \%$ & $330 \%$ & $8,00 \%$ & $-0,67 \%$ & $23,7 \%$ & $330 \%$ & $8,00 \%$ & $0,83 \%$ \\
\hline & $41,8 \%$ & $330 \%$ & $12,00 \%$ & $-0,67 \%$ & $36,9 \%$ & $330 \%$ & $12,00 \%$ & $0,83 \%$ \\
\hline
\end{tabular}

Source: Own elaboration.

The analysis uses a dynamic interpretation of the golden rule of debt in order to analyze the evolution of debt-toGDP ratios through time and determine which factors affect them and how much. The dynamic equation is given by

$D_{t}=\frac{1+i_{t}}{\left(1+\pi_{t}\right) \times\left(1+g_{t}\right)} \times D_{t-1}-\mathrm{PDR}_{t}+e_{t}$,

where $D_{t}$ is the level of debt in period $t, i_{t}$ denotes interest rate, $\pi_{t}$ stands for the inflation rate of the GDP deflator, PDRt is the primary deficit ratio (we may alternatively use PSRt with a negative sign), and $e_{t}$ is a residual that takes into account valuation effects and other accounting adjustments not fully captured by changes in the primary deficit. The other variables are similar to those in Eq. (1), with $i_{t}$ here being in nominal terms and $g_{t}$ in real terms. The decomposition of debt dymanics is based on a linearized version of (2). The results observed are as follows. First, the difference between the real interest rate and the real GDP growth plays a crucial role in determining the stability of public debt. For the 22 advanced economies in the database, the average difference was $-0.7 \%$. Besides, primary deficits respond slowly to changes in debt; hence the evolution of the stock of debt tends to be quite persistent and to undergo large, long swings. Second, the largest debt reductions were a result of high inflation in most cases, while in the rest this was still an important contributor to debt reduction. However, there is no clear correlation between growth and debt reduction in this group of high-debt episodes. Third, when these countries reached high levels of debt, their fiscal balances and inflation rates differed considerably. However, the more modern episodes are much more tightly clustered, with modest inflation rate and modest primary surplus. Fourth, while entering a high-debt phase is usually followed by relatively low growth, ${ }^{42}$ the study yields two additional observations: it matters whether a country's debt level is increasing or decreasing (decreasing levels of debt are correlated with periods of better growth performance, a result particularly striking for debt levels between 90 and $115 \%$ of GDP), and when this dichotomy increasing versus decreasing debt is introduced, there is no particular threshold that consistently precedes subpar growth performance. ${ }^{43}$

When the 26 episodes are separated into two broad categories, those in which debt levels increased and those in which they decreased (see Tables 10 and 11), three complementary results can be drawn.

On one hand, debt reduction ultimately requires primary surpluses. Indeed, the primary fiscal surplus is, on average, significantly higher during episodes where the debt-to-GDP ratio decreases $(2.4 \%)$ than when it increases $(1.2 \%)$. On the other hand, the relationship between inflation and debt

\footnotetext{
42 A result consistent with Reinhart and Rogoff (2010b)'s findings. 43 The report stresses that they do not mean to dispute the notion that, all else equal, higher levels of debt may lead to higher interest rates. Rather, it highlights that there is no simple relationship between debt and growth.
} 
Table 10 Episodes with an overall reduction in debt to GDP over 15 years.

\begin{tabular}{llcccc}
\hline & Start year & Change in debt-to-GDP (\%) & GDP growth (\%) & Inflation (\%) & PSR (as \% of GDP) \\
\hline Germany & 1918 & -129 & 1.2 & $1.4 \times 10^{10}$ & $\ldots$ \\
Japan & 1942 & -96 & 0.7 & 91.4 & 3.8 \\
Ireland & 1986 & -74 & 6.1 & 2.8 & 3.5 \\
Italy & 1942 & -68 & 2.8 & 41.5 & $\ldots$ \\
U.S. & 1946 & -68 & 1.4 & 3.0 & 1.7 \\
Greece & 1931 & -57 & -2.8 & 90.0 & 3.5 \\
Belgium & 1940 & -55 & 2.2 & 3.1 & 0.7 \\
Italy & 1919 & -43 & 0.1 & 2.7 & 2.0 \\
Spain & 1898 & -27 & 1.1 & 0.3 & 3.9 \\
Israel & 1977 & -22 & 2.2 & $\ldots$ & $\ldots$ \\
Belgium & 1921 & -22 & 1.3 & 1.8 & 0.8 \\
Canada & 1995 & -18 & 1.7 & -0.2 & 2.0 \\
Netherlands & 1887 & -15 & 0.1 & -0.6 & 1.3 \\
France & 1884 & -13 & 1.7 & 1.3 & 3.3 \\
Italy & 1992 & -2 & 1.4 & 1.0 & 2.8 \\
Average & & -47 & 1.8 & 2.1 & 2.8 \\
Excluding hyperinflation & & -33 & &
\end{tabular}

Source: IMF (2012d).

Table 11 Episodes with an overall increase in debt to GDP over 15 years.

\begin{tabular}{llccrc}
\hline & Start year & Change in debt to GDP (\%) & GDP growth (\%) & Inflation (\%) & PSR (as \% of GDP) \\
\hline Italy & 1876 & 4 & 0.6 & -0.2 & 4.1 \\
Belgium & 1983 & 8 & 2.0 & 2.5 & 2.1 \\
Greece & 1993 & 10 & 3.3 & 4.7 & 0.4 \\
New Zealand & 1884 & 28 & 0.6 & -1.6 & $\ldots$ \\
Canada & 1932 & 29 & 4.5 & 2.1 & -3.7 \\
New Zealand & 1909 & 36 & 0.5 & 3.8 & $\ldots$ \\
France & 1916 & 50 & 1.4 & 1.0 & 4.2 \\
Greece & 1888 & 75 & -0.2 & -4.3 & 0.5 \\
U.K. & 1918 & 75 & 0.0 & 4.7 & 8.2 \\
Netherlands & 1932 & 109 & 0.5 & -0.3 & 0.5 \\
Japan & 1997 & 131 & 1.3 & 2.2 & -5.4 \\
Average & & -47 & & 1.2 \\
\hline
\end{tabular}

Source: IMF (2012d).

reduction becomes more ambiguous. While hyperinflation ${ }^{44}$ is clearly associated with sharp debt reduction, when hyperinflation episodes are excluded there is no clear association. Finally, relatively stronger growth performance is now associated with debt reduction when hyperinflation episodes are excluded.

Another relevant result for the purposes of this paper is that though the analysis shows no clear association between inflation and debt reduction when hyperinflation episodes are excluded, it is observable from the data above that no deflation episodes are related to a debt reduction scenario. The lowest inflation associated with an overall reduction in debt-to-GDP ratio are France $1884(-0.6 \%)$ and Netherlands $(-0.2 \%)$, while the lowest observation in all the 20th century is Canada 1995, with an inflation of $1.9 \%$. All these three

\footnotetext{
44 Hyperinflation here is defined as an annual inflation above $40 \%$.
}

episodes are associated with the lowest effect over debt reduction, about $15 \%$ (see Table 10 ). On the contrary, four deflation episodes are associated with an overall increase in the ratio (see Table 11).

This finding is also consistent with the evidence from the six case studies analyzed in detail. These are the U.K. 1918, the U.S. 1946, Belgium 1983, Italy 1992, Canada 1995 and Japan 1997. These episodes cover the full range of macroeconomic policy approaches and reflect the full range of outcomes. In particular, the report stresses that the U.K. 1918 experience provides important lessons about fiscal austerity and the difficulties created by deflation, though the Japan 1997 similar experience shows this lesson has not been consigned to the dustbin of history. After World War I, the U.K. authorities implemented a policy mix of large expenditure decreases and tight monetary inflation (rising interest rates to $7 \%$ ). This caused weak growth, high unemployment and deflation. Primary surpluses contributed to reduce debt about 7 percentage points a year, but they 
were easily overwhelmed by deflation and high interest rates, which added 12 . As a consequence, debt continued to rise: it was not until 1990 that debt approached its pre-World War I level.

The outcome of the U.K. policy mix is more clearly attributed to the monetary stance when compared to the cases of Japan and U.S. Japan implemented tight monetary conditions and loose fiscal conditions and failed; the U.S., instead, succeeded with loose monetary conditions and tight fiscal conditions. Clearly, our results in Section 3 are coherent with the most relevant historical finding in the IMF paper: low growth and deflation make success of fiscal consolidation really hard to achieve. Besides, the 'financial repression' approach implemented by American authorities (a bond-support programme which placed a floor under the price of government bonds, preventing the Federal Reserve from raising interest rates to control inflation) would support the idea that ECB should be buying bonds of the peripheral countries in the Eurozone. ${ }^{45}$ Finally, the Japanese experience also highlights the need to deal with banking sector weakness - an ongoing strategy now in the Eurozone.

Comparing our results with those of the IMF's analysis we may propose a set of policy recommendations for the GIPSI countries. The six most important would be as follows:

(1) High levels of debt reduce potential GDP growth, with this relationship being more clear when debt continues to increase. The GIPSI countries have all reached high levels of debt and/or they are increasing their debt stocks. Therefore, a strategy for these countries to stop this performance somehow seems now a clear necessity.

(2) The difference between the real interest rate and the real GDP growth plays a crucial role in determining the stability of public debt. Given the high risk premia GIPSI countries are required to pay, higher nominal growth rates are desirable, as well as the support of the European authorities (ECB intervention, bailout programmes) to temporarily reduce the cost of debt.

(3) Debt reduction requires primary surpluses, but primary deficits have historically responded slowly to changes in debt. GIPSI countries must learn the lessons of history and focus on reducing deficits, but do it only as long as it does not damages growth. Hence, smooth and gradual consolidations are to be preferred.

(4) High growth helps reducing the burden of debt, and it has been indeed associated with debt reduction when hyperinflation episodes are excluded.

(5) The largest debt reductions have been a result of high inflation, but today we know episodes of hyperinflation are not desirable. When hyperinflation episodes are excluded there is mixed evidence between low inflation

\footnotetext{
45 This idea is supported by several authors, like Reinhart and Sbrancia (2011) and Reinhart et al. (2011). However, the IMF considers less clear this approach would be applied in today's economic environment. To mitigate the rise in inflation, the US authorities introduced consumer credit limits and there was a call for voluntary restraints on bank credit. The set of controls and regulations that would be equivalent today for this financial repression to be effective would lead to a less internationally integrated financial system.
}

and debt reduction. However, a clear result is that no deflation episodes have been associated with a debt reduction scenario. In particular, the experiences by the UK 1918 and Japan 1997 provide important lessons about fiscal austerity and the difficulties created by deflation.

(6) Finally, the external environment has been an important contributor to outcomes in the past. However, things are not looking so good today: IMF mentions the widespread consolidation efforts, deleveraging pressures from the private sector and adverse demographic trends as handicaps for GIPSI countries in the future. European authorities and European countries should be aware of this, promoting economic policies in accordance with what GIPSI countries need.

The IMF report concludes with the analysis of Belgium 1983, Italy 1992, and Canada 1995 experiences. They are shown to be good examples that debt can also be reduced in a context of low to moderate inflation. The economic policies should then focus on both implementing appropriate structural reforms that boost growth and achieve primary surplus, while monetary policy should be as supportive as possible. That is basically what our results in Section 3 describe: achieving primary surplus is an essential goal as long as it does not damages growth, and this is also a doublesided lesson - low growth and deflation make success of fiscal consolidation really hard to achieve. Finally, the Eurozone should help making the external environment more suitable for the GIPSI countries to succeed. This includes to postpone the fiscal consolidation of the European core countries, a more supportive monetary policy, accepting higher levels of inflation in countries with trade surplus, and fiscal stimuli though the budget of the EU, the European Investment Bank and several other mechanisms that help peripheral countries to achieve the economic growth they need.

\section{Concluding remarks}

In this paper we surveyed the theoretical and empirical literature on public sector deleverage and fiscal consolidation, and summarized the main consensus available regarding the negative effects of high public debt levels over economic performance, the requirements for debt to be sustainable, the role of debt as a fiscal policy tool, and the strengths and weaknesses of fiscal consolidations.

We also examined several macroeconomic scenarios, using data from the peripheral countries in the Eurozone (the so-called GIPSI countries), in order to better understand the growth versus austerity dilemma. We show the ability to deleverage is higher for high levels of growth and moderate levels of inflation. We provide a solvency ranking based on our analysis, but observe Italy and Ireland are paying a lower risk premium compared to Spain, contrary to what our results would suggest. We see a double reason for this: the sustainability of public debt is also affected by private indebtedness, particularly when it is the public sector who ends up guaranteeing these private debts; and Spain faces a lack of credibility to balance its public finances - unlike Italy, for instance. 
Finally, and by comparing our results with those of IMF (2012d)'s study, we proposed a set of policy recommendations for the GIPSI countries. These recommendations can be recorded as follows. First, a strategy to reduce GIPSI countries' high levels of debt and/or increasing debt stocks is now urgent. Second, the high risk premia these countries are required to pay at the markets make higher nominal growth rates necessary. Support by the European authorities (ECB intervention, bailout programmes) to temporarily reduce the cost of debt would also be desirable. Third, GIPSI countries must learn the lessons of history and focus on reducing deficits by obtaining primary surpluses, but only as long as it does not damage growth. Hence, smooth and gradual consolidations are to be preferred. Fourth, hyperinflation episodes are not desirable, but neither deflation: the experiences by the U.K. 1918 and Japan 1997 show the difficulties created by deflation. Fifth, GIPSI countries urge a gentle external environment. The Eurozone should postpone the fiscal consolidations by the European core countries, promote a more supportive monetary policy, accept higher levels of inflation in countries with trade surplus, and implement fiscal stimuli that help peripheral (GIPSI) countries to achieve the economic growth they need. Finally, GIPSI countries should focus in the meantime their efforts on implementing appropriate structural reforms that boost growth and achieve fiscal consolidation.

\section{Acknowledgements}

Insightful comments and suggestions by A. Costas, F. del Río and D. García-Coto are gratefully acknowledged. M.A. also acknowledges financial aid received from the Galician Regional Government (Xunta de Galicia) through Grant GPC 2013-045.

\section{References}

Aiyagari, S.R., Christiano, L., Eichenbaum, M., 1992. The output, employment, and interest rate effects of government consumption. Journal of Monetary Economics 30, 73-86.

Alesina, A., Ardagna, S., 1998. Tales of fiscal adjustments. Economic Policy 13, 487-545.

Alesina, A., Favero, C., Giavazzi, F., 2012. The output effect of fiscal consolidations. In: Growth and Sustainability Policies for Europe (GRASP) Project. European Commission, Available from: http://www.economics.harvard.edu/faculty/alesina

Alesina, A., Perotti, R., Tavares, J., 1998. The political economy of fiscal adjustments. Brookings Papers on Economic Activity 1, 197-266.

Altig, D., Christiano, L., Eichenbaum, M., Lindé, J., 2011. Firmspecific capital, nominal rigidities and the business cycle. Review of Economic Dynamics 14, 225-247.

Andrés, J., Doménech, R., 2012. The arithmetic of (excessive?) fiscal consolidation in Spain. VoxEu 07/04/2012, Available from: http://www.voxeu.org/article/arithmetic-excessive-fiscalconsolidation-spain

Auerbach, A., 2009. Long-term objectives for government debt. FinanzArchiv/Public Finance Analysis 65, 472-501.

Barro, R., 1974. Are government bonds net wealth? Journal of Political Economy 82, 1095-1117.

Barro, R., 1979. On the determination of the public debt. Journal of Political Economy 87, 940-971.
Barro, R., 1981. Output effects of government purchases. Journal of Political Economy 89, 1086-1121.

Batini, N., Callegari, G., Melina, G., 2012. Successful austerity in the United States, Europe and Japan. IMF Working Paper WP/12/190, International Monetary Fund.

Baxter, M., King, R., 1993. Fiscal policy in general equilibrium. American Economic Review 83, 315-334.

Bencek, D., Klodt, H., 2011. The Kiel Institute Barometer of Public Debt. Institut für Weltwirtschaft, Available from: http://www.ifw-kiel.de/think-tank/policy-support/The-KielInstitute-Barometer-of-Public-Debt $\% 20$

Bodenstein, M., Erceg, C.J., Guerrieri, L., 2009. The effects of foreign shocks when US interest rates are at zero. Bd. Governors, Fed. Reserve System, Washington, DC.

Braun, R.A., Waki, Y., 2006. Monetary policy during Japan's lost decade. Japanese Economic Review 57, 324-344.

Briley, R.A., Myers, S.C., Marcus, A.J., Mateos, P., 2010. Finanzas Corporativas. McGraw-Hill, Madrid.

Burnside, C., Eichenbaum, M., Fisher, J., 2004. Fiscal shocks and their consequences. Journal of Economic Theory 115, 89-117.

Cecchetti, S., Mohanty, M., Zampolli, F., 2011. The real effects of debt. BIS Working Papers No. 352, Bank for International Settlements.

Chari, V.V., Kehoe, P., McGrattan, E., 2009. New Keynesian models: not yet useful for policy analysis. American Economic Journal: Macroeconomics 1, 242-266.

Christiano, L., 2004. The zero-bound, zero-inflation targeting, and output collapse. Northwestern University, Mimeo.

Christiano, L.J., Einchenbaum, M., Rebelo, S., 2011. When is the government spending multiplier large? Journal of Political Economy 119, 78-121.

Coenen, G., Wieland, V., 2003. The zero-interest rate bound and the role of the exchange rate for monetary policy in Japan. Journal of Monetary Economics 50, 1071-1101.

Cogan, J.F., Cwik, T., Taylor, J.B., Wieland, V., 2010. New Keynesian versus old Keynesian government spending multipliers. Journal of Economic Dynamics and Control 34, 281-295.

Correia, I., Farhi, E., Nicolini, J.P., Teles, P., 2010. Policy at the Zero Bound. Bank of Portugal, Lisbon.

Corsetti, G., Meier, A., Müller, G.J., 2009. Fiscal stimulus with spending reversals. IMF Working Paper 09/106.

Corsetti, G., Kuester, K., Meier, A., 2010. Debt consolidation and fiscal stabilization of deep recessions. American Economic Review 100, 41-45.

de la Dehesa, G., 2012a. Austeridad y crecimiento: evidencia empírica. El País 20/05/12, Available from: http://economia. elpais.com/economia/2012/05/18/actualidad/1337340840 690230.html

de la Dehesa, G., 2012b. Dos reglas fiscales diferentes. El País 03/02/12, Available from: http://economia.elpais.com/ economia/2012/02/03/actualidad/1328291690_709266.html

Devereux, M., Head, A.C., Lapham, M., 1996. Monopolistic competition, increasing returns, and the effects of government spending. Journal of Money, Credit, and Banking 28, 233-254.

Devries, P., Guajardo, J., Leigh, D., Pescatori, A., 2011. A new action-based dataset of fiscal consolidation. IMF working paper No. $11 / 128$

Eggertsson, G., 2004. Monetary and fiscal coordination in a liquidity trap. In: Optimal Monetary and Fiscal Policy in the Liquidity Trap (Chapter 3, Ph.D., Princeton University).

Eggertsson, G., 2010. The paradox of toil. Federal Reserve Bank of New York Staff Report No. 433.

Eggertsson, G., Woodford, M., 2003. The zero interest-rate bound and optimal monetary policy. Brooking Papers of Economic Activity $1,139-211$.

Eggertsson, G., Krugman, P., 2012. Debt, deleveraging, and the liquidity trap: a Fisher-Minsky-Koo approach. The Quarterly Journal of Economics 121, 1469-1513. 
European Commission, 2012. Interim forecast: February 2012, Press Conference February 2012, Available from: http://ec.europa.eu/economy_finance/articles/eu_economic_ situation/pdf/2012/2012-02-23- interim-forecast_en.pdf

European Council, 2012. Treaty on Stability, Coordination and Governance in the Economic and Monetary Union.

Feldstein, M., 2003. Rethinking stabilization. Federal Reserve Bank Kansas City.

Finger, H., Sadikov, A., 2010. Reducción de la deuda pública. Finanzas \& Desarrollo (junio), 36-38.

Fisher, I., 1933. The debt-deflation theory of Great Depressions. Econometrica 1, 337-357.

Galí, J., López-Salido, J.D., Vallés, J., 2007. Understanding the effects of government spending on consumption. Journal of the European Economic Association 5, 227-270.

Giavazzi, F., Pagano, M., 1990. Can severe fiscal contractions be expansionary? Tales of two small European countries. In: Blanchard, O.J., Fischer, S. (Eds.), NBER Macroeconomics Annual. MIT Press, pp. 75-110.

Hall, R.E., 2011. The long slump. American Economic Review 102, 431-469.

Hernández de Cos, P., Thomas, C., 2012. El impacto de la consolidación fiscal sobre el crecimiento. Una ilustración para la economía española a partir de un modelo de equilibrio general. Documentos ocasionales n ${ }^{\circ} 1205$, Banco de España.

International Monetary Fund, 2012a. Fiscal monitor April 2012, Available from: http://www.imf.org/external/pubs/ $\mathrm{ft} / \mathrm{fm} / 2012 / 01 / \mathrm{pdf} / \mathrm{fm} 1201 . \mathrm{pdf}$

International Monetary Fund, 2012b. Fiscal monitor update, Available from: http://www.imf.org/external/pubs/ $\mathrm{ft} / \mathrm{fm} / 2012 /$ update/02/pdf/0712.pdf

International Monetary Fund, 2012c. World Economic Outlook 2012, April 2012, Available from: http: / /www.imf.org/external/pubs/ ft/weo/2012/01/pdf/text.pdf

International Monetary Fund, 2012d. World Economic Outlook 2012, October 2012, Available from: http://www.imf.org/external/ pubs/ft/weo/2012/02/pdf/text.pdf

Keynes, J.M., 1936. The General Theory of Employment, Interest, and Money. Macmillan, Londres.

Koo, R., 2008. The Holy Grail of Macroeconomics: Lessons from Japan's Great Recession. Wiley, New York.

Krugman, P., 1998. It's baaack: Japan's slump and the return of the liquidity trap. Brookings Papers on Economic Activity 2, 137-187.

Kumar, M.S., Woo, J., 2010. Public Debt and Growth. IMF Working Papers No. 10/174, International Monetary Fund.

Mankiw, N.G., 2006. The macroeconomist as scientist and engineer. Journal of Economic Perspectives 20, 29-46.

McKinsey Global Institute, 2011. Debt and deleveraging: the global credit bubble and its economic consequences, July 2011.

McKinsey Global Institute, 2012. Debt and deleveraging: uneven progress on the path to growth, January 2012.
Mian, A., Sufi, A., 2011a. House prices, home equity-based borrowing, and the U.S. household leverage crisis. American Economic Review 101, 2132-2156.

Mian, A., Sufi, A., 2011b. What Explains High Unemployment? The Aggregate Demand Channel. University of Chicago, Mimeo.

Minsky, H., 1986. Stabilizing an Unstable Economy. Yale University Press, New Haven, CT.

Modigliani, F., Miller, M., 1958. The cost of capital, corporation finance and the theory of investment. American Economic Review 48, 261-297.

Monacelli, T., Perotti, R., 2008. Fiscal policy, wealth effects and markups. Working Paper No. 14584, NBER, Cambridge, MA.

Panizza, U., Presbitero, A.F., 2012a. Is high public debt harmful for economic growth? VoxEu 22/04/2012.

Panizza, U., Presbitero, A.F., 2012b. Public debt and economic growth: is there a causal effect? MoFiR Working Paper No. 65.

Perotti, R., 1999. Fiscal policy in good times and bad. Quarterly Journal of Economics 114, 1399-1436.

Ramey, V.A., 2011. Identifying government spending shocks: it's all in the timing. Quarterly Journal of Economics 126, 1-50.

Ramey, V.A., Shapiro, M.D., 1998. Costly capital reallocation and the effects of governments spending. Carnegie-Rochester Conference Series on Public Policy 48, 145-194.

Reinhart, C.M., Rogoff, K.S., 2009. This Time is Different: Eight Centuries of Financial Folly. Princeton University Press, Princeton, NJ.

Reinhart, C.M., Rogoff, K.S., 2010a. Debt and Growth Revisited. VoxEU.org 11/08/2010.

Reinhart, C.M., Rogoff, K.S., 2010b. Growth in a time of debt. American Economic Review: Papers and Proceedings 100, 573-578.

Reinhart, C.M., Sbrancia, M.B., 2011. The liquidation of government debt, NBER Working Paper No. 16893. National Bureau of Economic Research, Cambridge, MA.

Reinhart, C.M., Kirkegaard, J.F., Sbrancia, M.B., 2011. Financial Repression Redux. Finance and Development 48, 22-26.

Rotemberg, J., Woodford, M., 1999. Interest rate rules in an estimated sticky price model. In: Taylor, J.B. (Ed.), Monetary Policy Rules. University of Chicago Press and NBER.

Rotemberg, J., Woodford, M., 1992. Oligopolistic pricing and the effects of aggregate demand on economic activity. Journal of Political Economy 100, 1153-1297.

Sargent, T., Wallace, N., 1981. Some unpleasant monetarist arithmetic. Federal Reserve Bank of Minneapolis Quarterly Review 5.

Verhelst, S., 2012. How EU fiscal norms will become a safety net for the failure of national golden rules. European Policy Brief 6, EGMONT Royal Institute for International Relations.

Whelan, K., 2012. Golden rule or golden straightjacket? VoxEU.org 25/02/2012.

Woodford, M., 2009. Convergence in macroeconomics: elements of the new synthesis. American Economic Journal: Macroeconomics $1,267-279$ 